IZA DP No. 6809

Trade Liberalization and Female Labor Force Participation: Evidence from Brazil

Isis Gaddis

Janneke Pieters

August 2012 


\title{
Trade Liberalization and Female Labor Force Participation: Evidence from Brazil
}

\author{
Isis Gaddis \\ University of Göttingen
}

Janneke Pieters

$I Z A$

Discussion Paper No. 6809

August 2012

IZA

P.O. Box 7240

53072 Bonn

Germany

Phone: +49-228-3894-0

Fax: +49-228-3894-180

E-mail: iza@iza.org

Any opinions expressed here are those of the author(s) and not those of IZA. Research published in this series may include views on policy, but the institute itself takes no institutional policy positions.

The Institute for the Study of Labor (IZA) in Bonn is a local and virtual international research center and a place of communication between science, politics and business. IZA is an independent nonprofit organization supported by Deutsche Post Foundation. The center is associated with the University of Bonn and offers a stimulating research environment through its international network, workshops and conferences, data service, project support, research visits and doctoral program. IZA engages in (i) original and internationally competitive research in all fields of labor economics, (ii) development of policy concepts, and (iii) dissemination of research results and concepts to the interested public.

IZA Discussion Papers often represent preliminary work and are circulated to encourage discussion. Citation of such a paper should account for its provisional character. A revised version may be available directly from the author. 


\section{ABSTRACT}

\section{Trade Liberalization and Female Labor Force Participation: Evidence from Brazil ${ }^{*}$}

While there is a large literature analyzing the distributional impacts of trade reforms across the income or skill distribution, very little is known about the gender effects of trade reforms. This paper seeks to fill this gap and investigates the impact of Brazil's 1987-1994 trade liberalization on labor force participation of women. To identify the causal effect of trade reforms we exploit exogenous variation in exposure to tariff reductions across states linked to spatial differences in states' initial industry composition. We find that tariff reductions were associated with an increase in female labor force participation and employment after a period of around two years. Our results are robust to a variety of different approaches in dealing with the potential endogeneity of regional exposure to trade liberalization, alternative measures of trade protection and different time periods. Moreover, we find evidence that employment flows across sectors, especially an accelerated shift from agriculture and manufacturing to trade and other services, but also greater labor market insecurity and male unemployment are behind the observed increase in female economic activity. This suggests that both push and pull factors induced women to join the labor force.

JEL Classification: F13, F16, J16, J21, O15

Keywords: female labor force participation, trade liberalization, Brazil

Corresponding author:

Janneke Pieters

IZA

P.O. Box 7240

53072 Bonn

Germany

E-mail: pieters@iza.org

\footnotetext{
* We would like to thank Jérémie Gignoux and Phillippe Leite for sending us data and helpful auxiliary files. We also thank Stephan Klasen, Jann Lay, Jenny Aker, and seminar participants in Goettingen for valuable comments. Of course, all errors are our own.
} 


\section{Introduction}

Women's rising economic activity is an ongoing phenomenon across advanced and many developing (particularly Latin American) countries. Over the past three decades, rising female labor force participation largely occurred against the backdrop of globalization, one of its most notable features being rapid trade liberalization and the increasing integration of world product markets. The sharp decline in international tariff barriers in developing countries since the 1980s has motivated a rich literature to analyze the distributional impacts of trade reforms, typically across the income or skill distribution (see Goldberg and Pavcnik 2007 for an overview). However, so far there is only very limited empirical evidence on the gender effects of trade liberalization in developing countries, in particular regarding its effects on female labor force participation. This is the focus of the present paper, which seeks to investigate the impact of Brazil's 1987-1994 trade liberalization on women's economic activity.

Recent empirical work at the cross-country level on the gender effects of globalization and trade has been inconclusive. Some authors have analyzed the empirical relationship between trade flows and female labor force participation across countries (e.g. Wood 1991; Cagatay and Ozler 1995; Meyer 2006; Gray, Kittilson and Sandholtz 2006; Bussman 2009; Cooray, Gaddis and Wacker 2012). These studies often find heterogeneous effects of trade on women's economic activity, contingent on the country's income level and economic structure and the time period considered. However, these analyses also face significant methodological challenges particularly regarding the quality and international comparability of labor force data, and the difficulty to establish causality in a cross-country framework, where trade flows may be correlated with other factors determining female economic activity. An attractive alternative is to use micro data from household, labor force and establishment surveys. Several studies have documented a positive association between export-orientation and female employment at the establishment level (e.g. Cagatay and Berik 1990; Ozler 2000; Pradhan 2005; Ederington, Minier and Troske 2010) but the results are typically confined to the manufacturing sector and based on simple OLS regressions, thus lacking a meaningful causal interpretation. In sum, there has been very little (if any) evidence on the causal effect of trade liberalization on female labor market outcomes so far.

This study seeks to fill this gap by presenting robust empirical evidence on the impact of trade reforms on women's labor force participation. We thereby contribute to the empirical literature on trade and female labor force participation discussed above, but also to the broader literature on the distributional effects of trade liberalization (e.g. Goldberg and Pavcnik 2007; Topalova 2007, 2010). We examine the Brazilian experience of trade liberalization in the late 1980s and early 1990s to make three important contributions:

First, we use exogenous variation in exposure to tariff reductions across federal states, which is linked to spatial differences in states' initial industry composition, to identify the causal effect of trade liberalization on women's labor market outcomes. To do so we combine nationally representative household survey data from Brazil's National Household Sample Surveys (PNAD) for the period 1987 to 1996 with external data on tariffs and effective rates of protection at the industry-level to construct a measure of exposure to trade protection at the state-level. This exposure index varies both over time and across regions, because the intensity with which a state is affected by trade reforms depends on the initial sectoral composition of employment within the state and the magnitude of sectoral tariff changes. By comparing changes in exposure to trade protection across states we can identify the relative impact of trade liberalization on female labor 
market outcomes, whilst controlling for secular trends and time-invariant regional unobservable factors. The identification strategy we use in this paper has been previously applied to estimate the impact of trade policy changes on poverty and inequality outcomes (Topalova 2007, 2010; Castilho, Menéndez and Sztulman 2012), child labor and human capital (Kis-Katos and Sparrow 2011; Edmonds, Pavcnik and Topalova 2010) and local labor market effects (Kovak 2011). However, this is to our knowledge its first application to estimate the impact of trade reforms on labor market outcomes specifically of women.

Second, unlike much of the existing microeconomic literature we do not restrict the analysis to the manufacturing sector, but focus on economy-wide changes across all sectors. Restricting the analysis to the manufacturing sector only provides a very partial picture, because women are overrepresented in the non-tradable service sectors, which are indirectly affected by tariff reductions in the tradable sectors. Moreover, using the state as the unit of analysis helps us to overcome selection effects typically encountered by analyses confined to any one sector. In fact our econometric set up should reveal general equilibrium effects taking place within federal states, though not any effects operating between states.

Third, we not only estimate the effect of trade liberalization on female labor market participation, but examine a wider range of female labor market outcomes (including employment in different sectors and unemployment). Moreover we test for heterogeneous effects on different socioeconomic groups of women, and explore the mechanisms through with trade reforms affected female labor market outcomes. This allows us to obtain a more rounded and nuanced picture of the effects of trade reforms on women's economic position, and to investigate potential transmission channels.

It should be emphasized that the focus of this paper lies on the short- to medium-term effects of trade liberalization on women's participation in the labor market. Over longer time periods trade liberalization induced opportunities and incentives should cause cross-regional migration, which would act as an equalizing force and dampen the regional labor market effects observed in the initial years after the reforms (see also Kovak 2011). Moreover, our identification strategy only allows estimating the differential impact of tariff reforms on female labor market outcomes across Brazil's federal states, but not any country-wide 'level' effects of trade liberalization - e.g. if trade reforms affect the country's overall growth trajectory (Topalova 2007, 2010). Finally it should be emphasized that this paper estimates a reduced-form relationship between tariff reductions and female labor market outcomes, which inherently leaves many questions open regarding the mechanisms at work. And even while the second part of the empirical analysis provides further insights into potential transmission channels, we do not estimate a structural model that rigorously traces the causal chain from trade liberalization via goods and factor markets to female labor force participation.

Brazil presents an excellent context to study the impact of trade liberalization on female labor market outcomes. Previously one of the most protected countries in the world, the Brazilian government embarked on a policy of significant, yet gradual, tariff reductions in the late 1980s and early 1990s as a response to GATT/WTO negotiations. It has been widely acknowledged that these reforms had profound effects on labor markets, poverty and inequality outcomes (Green, Dickerson and Abache 2001; Goldberg and Pavcnik 2003; Pavcnik, Blom, Goldberg and Schady 2004; Gonzaga, Menezes-Filho and Terra 2006; Ferreira, Leite and Wai-Poi 2010; Kovak 2011; Castilho, Menéndez and Sztulman 2012). Moreover, being the largest country in South America 
with significant geographical heterogeneity in the structure of production, there is spatial variation in exposure to trade reforms over time, which offers a valuable identification strategy to isolate the effect of trade liberalization on female labor market outcomes. Finally, we can take advantage of a comparable annual time series of household survey data (the PNAD), with an average sample size of just above 300,000 individuals for the main period under investigation and detailed information on labor market participation. Such a rich data set is available only in very few developing countries.

Our results show that declining trade protection in Brazil over the late 1980s and early 1990s was associated with growing female labor force participation and employment with a lag of about two years. These results appear to be robust to a variety of approaches in dealing with the potential endogeneity of regional exposure to trade protection, alternative measures of trade protection and different time periods, which we regard as an important validation of our identification strategy. Moreover, we find support for the notion that sectoral changes in the structure of production and employment (esp. an accelerated shift from agriculture and manufacturing to trade and other services) as well as greater labor market insecurity and male unemployment are behind the observed increase in female economic activity. This suggests that both push and pull factors caused women to join the labor force.

This paper is structured as follows. Section 2 reviews the existing theoretical and empirical literature on the effects of trade liberalization of female labor force participation. Section 3 describes the data sources used in this study, presents a short narrative of the Brazilian trade liberalization and shows descriptive trends in women's economic activity. Section 4 first describes our trade protection measure and the empirical framework. It then discusses how trade liberalization affected female labor market outcomes in Brazil and establishes the robustness of the estimated effects. Section 5 explores potential transmission channels that could explain the reduced form relationship between trade reforms and women's labor market participation. Section 6 concludes.

\section{Theory and Literature}

Trade liberalization can influence female labor market outcomes through a variety of channels. Any discussion of the labor market effects of trade liberalization typically starts with the predictions of neoclassical trade theory, particularly the Heckscher Ohlin (HO) model and the closely linked Stolper-Samuelson theorem. Both models are of general-equilibrium nature and have profoundly influenced economists' thinking regarding the distributional effects of trade reforms, even though some of the models' predictions have found little empirical support (Goldberg and Pavenik 2007). In its simplest version, the HO-model of comparative advantage suggests that static efficiency gains from international specialization and exchange induce a structural change in production and reallocation of input factors towards those sectors that use a country's abundant factor most intensively. The Stolper-Samuelson theorem adds that this will lead to a rise in the real returns of the factor used intensively in the production of the expanding sector, while the other factor's remuneration declines (Winters 1991). 
A potential reason why a sectoral reallocation of production and resources may have gender implications is that male and female labor may be imperfect substitutes in the production process, such as in the models of Galor and Weil (1996), Knowles, Lorgelly and Owen (2002), Sauré and Zoabi (2009) and Rees and Riezman (2012). The effects of trade liberalization on male and female labor market outcomes then depend on the countries' initial factors endowments (which determine the direction of specialization), and the properties of the production functions. Sauré and Zoabi (2009) demonstrate that the effects of trade liberalization on female employment can easily counteract common intuition. In their model, a trade liberalization-induced expansion in the sector that uses female labor intensively leads to a decline in female labor force participation. In the spirit of the Galor and Weil (1996) model they assume that men and women are equally endowed with 'brain' (mental labor), but men have more 'brawn' (physical labor) than women. This leads to a gender wage gap in favor of men as long as 'brawn' has a positive marginal return. ${ }^{1}$ Moreover, physical capital (e.g. machinery) is assumed to complement 'brain' more than 'brawn'. If the economy now specializes in female-labor intensive tasks, e.g. as a result of trade reforms, male workers (who do not face a trade-off between employment and child care activities) move to the expanding sector, depressing that sector's capital-to- 'brain' ratio. Due to the strong complementarity between capital and 'brain', the marginal product of 'brain' (with which men and women are equally well endowed) declines by more than the marginal product of 'brawn' (with which only men are endowed), thereby increasing the gender wage gap and depressing female labor force participation. In other words, male workers seeking to maximize their own labor market returns crowd out female workers. This shows that the direction of demand side induced changes in gender wage and employment gaps in response to an expansion of femalelabor-intensive sectors is ambiguous a priori, contingent on the properties of the production function.

But even if male and female labor are perfectly substitutable, sectoral changes in the structure of production may have gender implications if there are frictions that exhibit women from entering certain sectors. Goldin (1995) argues that society often stigmatizes female industrial workers, especially if they work in heavy industries (see also Boserup 1970). Similarly, gender specific differences in social and competitive preferences (Croson and Gneezy 2009) or in care-giving responsibilities (Becker 1981, 1985) can lead to a situation where female labor force participation depends on the sectoral structure of production. In fact, it has been widely observed that in virtually all countries women are clustered in particular occupations and sectors of the economy, often with little changes over time (Anker, Melkas and Korten 2003; World Bank 2011).

A sector that deserves specific attention in the context of trade liberalization induced structural change and female labor force participation is the non-tradable sector. In many countries women are disproportionately represented in the service sectors, such as in communal and personal services and trade (World Bank 2011). HO trade theory - in its simple '2-countries, 2-factors, 2goods' version - is silent on the effects of trade liberalization on the non-tradable sector. ${ }^{2}$ Basic macroeconomic theory often supposes that prices in the tradable sector influence prices in the non-tradable sector - because the factor labor is mobile, and equalizes wages between sectors.

\footnotetext{
${ }^{1}$ Women hence face a trade-off between fertility and labor force participation. On the contrary, men are always employed because their wages are higher and thus their opportunity cost of raising children.

${ }^{2}$ Subsequent authors (e.g. Komiya 1967; Jones 1974) have extended the HO-model to include a non-tradable sector, but the model's predictions are not readily generalizable (depending, for example, on the number of goods and factors).
} 
This assumption is underlying the Balassa-Samuelson model, which postulates that the productivity of labor in the tradable sector determines wages and prices in the non-tradable sector (Balassa 1964). Similar reasoning is presented in Kovak (2011), who argues that the non-traded sector price must track the traded goods prices. This would imply that if import liberalization lowers the price level of traded goods, non-traded sector prices move along and there is no further substitution between tradable and non-tradable goods under homothetic preferences, though the actual quantities consumed could still change if liberalization-induced price changes affect real incomes.

The notion that trade liberalization fuels structural change is based on the conjecture that labor is perfectly mobile between sectors. This assumption is relaxed in the specific factor model (Ricardo-Viner model), which assumes that one factor (e.g. machinery or skilled labor) is immobile between sectors, at least in the medium term (Edwards and Edwards 1994). This gives rise to industry-specific rents and implies that adjustments are more likely to operate via factor prices than via sectoral reallocations. Sectoral gender segregation in the labor market, due the reasons described above, may also lead to reduced or asymmetric cross-sectoral labor mobility. However, prices and wages may also not be perfectly flexible in the short-term, which increases the likelihood for short- to medium-term disequilibria in response to a trade liberalization shock, and prolonged adjustment phases. During the adjustment process, the informal sector can potentially play an important role because it may absorb labor shed in the formal sector (but see Maloney 2004 for a more nuanced discussion of the informal sector). Since often a large fraction of informal sector workers are in non-tradable services, the non-tradable sector may temporarily expand after trade liberalization. ${ }^{3}$

The empirical evidence on sectoral labor reallocations in response to trade liberalization is mixed. Goldberg and Pavcnik (2007), citing evidence from Mexico, Colombia, Morocco and India, argue that contrary to the predictions of neoclassical trade theory, most studies find little evidence of a substantial reallocation of labor across sectors after trade reforms. ${ }^{4}$ On the other hand, studies for Brazil demonstrate that trade liberalization has been associated with significant employment flows across sectors. Menezes-Filho and Muendler (2011), for example, find that trade liberalization increased transitions out of formal manufacturing into services. Other authors have documented declining industry-specific and economy wide skill premia (Ferreira, Leite and Wai-Poi 2010; Gonzaga, Menezes Filho and Terra 2006) and employment shifts from skill-intensive to unskilled sectors, which is consistent with the notion of trade-liberalization induced structural change given that Brazil's pre-reform tariffs were highest for skill-intensive products. Altogether, this indicates that employment flows across sectors could be a relevant mechanism for the analyses in this paper.

The dynamic effects of trade liberalization can also affect men and women differently, though these effects are more likely to gain full force over longer time periods. First of all, trade liberalization may induce skill-biased technological change, either because it creates incentives for firms to adopt new technologies (Wood 1995; Thoenig and Verdier 2003), or through the import of machinery from technologically advanced countries (Acemoglu 2003). If such capital

\footnotetext{
${ }^{3}$ Inter-sectoral production linkages can also play a role for the size of the non-tradable sector, for example if the expanding and contracting tradable sectors require different quantities of domestic services as inputs.

${ }^{4}$ However, most analyses are based on broadly aggregated sectors, which could easily mask significant changes in employment across more disaggregated sectors.
} 
investments are complementary to female labor (as assumed in the models by Galor and Weil 1996 and Sauré and Zoabi 2009), skill-biased technological change works towards rising female employment. If, on the other hand, these technologies are complementary to male labor, for example due to low levels of female education, women will be disadvantaged (a notion suggested by Berik 2000).

Competition is another channel through which trade liberalization could affect the gender composition of the work force. According to Becker's (1957) famous model of economic discrimination, employers having a 'taste for discrimination' of minority workers will be outcompeted by non-discriminating employers as competition increases. If trade liberalization enhances domestic competition, women could benefit from declining discrimination in the labor market (evidence for this is presented in Black and Brainerd 2004). The idea is further developed by Yahmed (2010), who argues that while increased import penetration triggers an increase in competition, better access to foreign markets acts in the opposite direction, increasing profit margins and thus enhancing discriminatory behavior. This highlights the need to distinguish between two potentially counteracting forces of (multilateral) trade liberalization - rising import penetration on the one hand, and increasing export orientation on the other hand. Others view liberalization and competition in much more pessimistic terms, arguing that trade liberalization reduces the bargaining power of female workers (e.g. Standing 1999).

The above discussion was centered on changes in demand for female labor due to trade liberalization. However, there are also supply side arguments - e.g. if trade liberalization changes male earnings, and thus overall family income. In fact, most labor supply models consider married women's labor force participation decision to be a function of their own wage offer, as well as their husbands' wages and non-wage incomes (Killingsworth and Heckman 1987; Goldin 1995; Blau and Kahn 2007, Heim 2007). Thus, if trade liberalization leads to a decline (or increase) in male labor income, women might increase (reduce) their labor supply via the income effect- esp. in countries that lack social insurance programs and functioning credit markets. Indeed there is empirical evidence that women in developing countries supply labor to smooth household consumption over the business cycle (Bhalotra and Umaña-Aponte 2010). Similarly, a large literature has documented the 'added worker' effect, which refers to an increase in the labor supply of married women triggered by the displacement or their husband or other decline in family income (e.g. Melvin 2002 for the US; Parker and Skoufias 2004 for Mexico; Priebe 2010 for Indonesia). ${ }^{5}$ This added-worker effect has been documented for Brazil by Fernandes and Felício (2005), who use data that span the period of trade reforms (1985-1999) and who show that wives are more likely to enter the labor force after their husband has become unemployed.

Altogether it seems that the net effect of trade liberalization on female labor market outcomes is ambiguous a priori, depending on which of several possible effects dominates in a specific country. Theory alone provides little guidance on the relative importance of these transmission channels, so that the effect of trade liberalization on female labor force participation ultimately becomes an empirical question. However, based on the existing empirical literature for Brazil, we hypothesize that sectoral labor reallocations and supply-side effects may have played an important role in the case of Brazil, and we focus on these two mechanisms in the empirical analysis.

\footnotetext{
${ }^{5}$ In a dynamic framework, a temporary unemployment spell of the husband could even affect expectations about future earnings and thus have repercussion on women's life cycle labor supply (Spletzer 1997).
} 
A number of studies have analyzed the relationship between trade and female economic activity on the basis of cross-country data, mostly focusing on trade flows, rather than trade policy changes. The results of this literature point to significant heterogeneity across regions and time spells. One of the earlier work in this category is Wood (1991), who argues that North-South trade increased the demand for female labor in the manufacturing sector in developing countries over the period 1960-1985 (largely driven by the East Asian economies). However, his findings are derived from simple over-time correlations and do not extend beyond the manufacturing sector. More recent work has taken an economy-wide perspective by focusing on the female labor force participation rate or the female share of the labor force. Here we focus on studies that base identification on over-time variation and panel econometric techniques. ${ }^{6}$

Bussman (2009) finds positive effects of trade (exports to GDP, import penetration) on female labor force participation in non-OECD countries, but negative effects in OECD countries, on the basis of GMM estimations for 1970 to 2000. Gray, Kittilson and Sandholtz (2006) focus on a similar time period (1975-2000) but use fixed effects estimations to examine the relationship between various indicators of globalization and female labor force participation. Trade openness (sum of exports and imports to GDP) comes out insignificant, but this could potentially be related to the fact that the analysis pools advanced and developing countries. Cooray, Gaddis and Wacker (2012) focus on the effects of globalization on female economic activity in developing countries (low income and lower middle income countries) over the time period 1980 to 2005. Using fixed effects regressions, they find a negative effect of trade (exports to GDP) on the labor force participation of young women. However, the magnitude and direction of the effects is contingent on the structure of production as the negative effect of trade on female economic activity is restricted to countries having a large service sector. In sum, the cross-country literature suggests that aggregate analyses hide significant heterogeneity across countries, age cohorts and time spells, which is consistent with the notion that the effects of trade liberalization on women's labor market outcomes depend on the pattern of structural change and other country-specific factors (see also Gaddis and Klasen 2012 regarding the effects of sectoral growth on female labor force participation). This highlights the need for micro-oriented analyses to better understand the various factors at work in the context of a specific country.

Turning to the microeconomic literature, several authors estimate the relationship between export orientation and women's employment. Studies at the establishment level in the manufacturing sector have documented a positive correlation between export-orientation and the share of female employees for Turkey (Cagatay and Berik 1990; Ozler 2000), Columbia (Ederington, Minier and Troske 2010) and India (Pradhan 2005). Others have found a positive correlation between regional variation in export orientation and female labor force participation (e.g. Baslevent and Onaran 2004 using data for Turkey). However, using cross-sectional variation to identify the relationship between export exposure and female employment can lead to biased results if there is latent unobserved heterogeneity, such as if exporters differ systematically from non-exporting firms.

A second strand of the literature explores the relationship between changes in trade policy and female employment. Gender effects of trade liberalization are sometimes discussed in the context

\footnotetext{
${ }^{6}$ This excludes work by Cagatay and Ozler (1995) and Meyer (2006), who base identification on cross-sectional variation and OLS estimations. We also do not discuss studies here that study the effects of globalization on gender wage gaps (e.g. Oostendorp 2009).
} 
of Computable General Equilibrium (CGE) models simulating the distributional implications of tariff changes. Terra, Bucheli and Estrades (2007) argue that trade liberalization would lead to an increase in female labor supply in Uruguay, mainly amongst educated women. In a similar analysis for Pakistan, Siddiqui (2009) finds that trade liberalization would raise female employment in unskilled jobs. While these analyses can be useful to inform policy makers on the likely effects of trade reforms in an ex-ante setting, the findings depend heavily on the structure and assumptions of the CGE model and cannot substitute for ex-post analysis of the impact of trade liberalization.

Despite the fact that there is a large micro-economic literature analyzing the wider distributional effects of trade liberalization, very few studies have explored the gender effects of trade reforms. What evidence there is comes from Mexico under NAFTA. Aguayo-Tellez, Airola and Juhn (2010) explore the role of between- and within-industry changes for female employment and wages. They argue that between-industry shifts, consistent with trade liberalization induced structural change, account for around one third of the growth in women's employment share between 1990 and 2000. Moreover, plant level data from the manufacturing sector document that the female share of the wage bill is higher amongst exporting firms - which may indicate that trade liberalization also contributed to increasing feminization within industries. While these results suggest that trade reforms in the context of NAFTA have contributed to rising female labor force participation in Mexico, the descriptive nature of the decomposition techniques and the limited scope of the plant-level analysis do not allow for the deduction of firm policy conclusions.

The present paper sets out to remedy the deficiencies of the existing empirical literatures and present more robust empirical evidence on the impact of trade reforms on women's economic activity and other labor market outcomes. We use an identification strategy pioneered by Topalova $(2007,2010)$, which exploits variation across federal states in exposure to sectoral tariff changes. The key econometric challenge in identifying the causal effect of trade liberalization is that national tariff reforms affect the whole country, leaving the analyst without a control group that could be suitably compared to households exposed to trade liberalization. However, geographic variation in the initial industry structure and the phased nature of sectoral tariff changes in Brazil suggest that there is variation in the intensity with which federal states were exposed to trade reforms over time. Hence by comparing states more or less exposed to trade reforms we can identify the relative impact of trade liberalization on female labor market outcomes. This idea is formalized in section 4 , which describes the trade exposure index and identification strategy.

\section{Trade Liberalization and Women's Work in Brazil - Data and Descriptive Evidence}

\subsection{Data Sources}

The data for the analysis are drawn from several different data sources. First, we use the Brazil National Household Sample Survey (PNAD), which is a nationally representative household survey fielded annually by the Brazilian Census Bureau (Instituto Brasileiro de Geografia e 
Estatística, IBGE). ${ }^{7}$ The PNAD data are collected using a stratified and clustered sample design that ensures representative coverage of urban and rural areas in all states of the federation, except for the rural parts of some Northern states (Acre, Amapá, Amazonas, Pará, Rondônia and Roraima), which were excluded until 2003 (Ferreira, Leite, Wai-Poi 2010; Castilho, Menéndez and Sztulman 2012). ${ }^{8}$ We mainly rely on the PNAD data for 1987 to 1996, which is the period coinciding with the Brazilian trade liberalization, but we also use PNAD data up to 2009 for the descriptive analysis to place our results into the perspective of long-term trends in female labor market outcomes in Brazil. The PNAD surveys of the late 1980s and 1990s covered between 70,000 and 90,000 households each year, corresponding to 300,000 to 350,000 individuals. The survey includes a detailed labor market module which is administered to all individuals aged 10 years or above.

While the PNAD used a fairly consistent survey instrument from 1992 onwards, there were some changes in the questionnaire between 1990 and 1992, which needed to be addressed for the analysis in this paper (see Helfand and Brunstein 2001 for a discussion). Prior to 1992, the PNAD surveys used a definition of employment which included economic activities remunerated in cash or in kind (irrespectively of the number of hours these activities were carried out) as well as unremunerated activities of at least 15 hours per week that had the objective of assisting an economically active household member or a non-profit institution. Activities related exclusively to the production for own consumption purposes were not considered as employment. As of 1992, IBGE has broadened the definition of employment, in particular lifting the 15 hours threshold for unpaid workers, and capturing all production of goods for own consumption purposes as employment. To account for these changes, we follow the recommendations in Helfand and Brunstein (2001) and construct a comparable employment variable series based on the definition used by the IBGE until 1992. We consider three main labor market outcomes labor force participation, employment and unemployment - all referring to the population aged 25 to 64 years $^{9}$ (see appendix A1 for details on the definitions of these variables).

Our second data source consists of data on nominal tariffs and effective rates of protection by sector based on Kume, Piani and de Souza (2003) and tabulated in Abreu (2004) for the period 1987 to $1999 .{ }^{10}$ We regard the effective rate of protection (ERP) as our main indicator of trade policy change. Compared to nominal tariffs, the effective rate of protection considers both tariffs on output products and imported intermediate goods and is thus a better measure of sectoral protection induced by the overall tariff structure (see Goldberg and Pavcnik 2007 for a discussion). However, we repeat the analysis using nominal tariffs, which are the most commonly used indicators to measure changes in trade policy (Kis-Katos and Sparrow 2011; Topalova 2007). Last but not least we use concordance tables developed by Ferreira, Leite and Wai-Poi (2010), which facilitate matching the PNAD activity codes with the tariff data.

\footnotetext{
${ }^{7}$ Data collection for the PNAD was suspended during the census years $(1990,2000)$, and due to budgetary reasons also in 1994.

${ }^{8}$ We combine the states Goiás and Tocantins, which were split up in the late 1980s.

${ }^{9}$ We thereby focus on a cohort of women that has largely completed educational attainment.

${ }^{10}$ While our trade protection data are available until 1999, there is very little variation in tariffs after 1997.
} 


\subsection{The Brazilian Trade Liberalization}

Until the late 1980s, Brazil was one of the most heavily protected economies in the world (Ferreira, Leite, Wai-Poi 2010). Despite the fact that the country was among the founding members of the General Agreement on Trade and Tariffs (GATT) in 1947, it made extensive use of GATT article XVIII:B, which allowed developing countries to impose trade restrictions to address balance of payment difficulties (Abreu 2004). In 1987, just before the onset of trade liberalization, average nominal tariffs stood at 54.9 percent, with significant variations between industries. Apparel (102.7 percent), automobiles ( 92.6 percent) and textiles ( 87.4 percent) were the most heavily protected sectors, while the lowest tariffs were applied to oil, gas and coal (15.6 percent), mining products (22 percent) and chemicals (25.4 percent). Due to the structure of tariffs, effective rates of protection showed even greater dispersion - varying between 308.1 percent in the automobile sector and just 8.3 percent for oil, gas and coal (Abreu 2004).

It should be noted that the structure of pre-liberalization tariff protection in Brazil showed a mild positive correlation with skill intensity (Gonzaga, Menezes-Filho and Terra 2006). As a consequence, later tariff reductions were highest for skill-intensive sectors, which sets Brazil apart from many other Latin American countries and has important implications for the direction of trade-liberalization induced labor reallocations (Ferreira, Leite and Wai-Poi 2010).

In the late 1980s, after the transition from military rule to a civilian government, Brazil embarked on an ambitious liberal reform agenda, whose central elements were a comprehensive trade liberalization program and macroeconomic stabilization to curb inflation. Between 1987 and 1994 average nominal tariffs were unilaterally lowered from 54.9 to 10.2 percent and most nontariff trade barriers were lifted. Tariff dispersion and escalation were reduced as well - so that nominal tariffs in 1994 ranged between zero protection in the mining sector and 23.5 percent for dairy products (Abreu 2004; see also figure A1 in the appendix).

Brazil's move to a more liberal trade policy stance was triggered by a series of external and internal events. Even though trade reforms were implemented unilaterally, they were embedded in multilateral trade negotiations under the Uruguay Round (Castilho, Menéndez and Sztulman 2012). Trade policy changes were also designed to have tariff levels converge towards the Mercosur Common External Tariff (CET), which came into effect with the establishment of Mercosur customs union in January 1995 (Abreu 2004). Yet the fundamental reversal in trade policy also had deeper causes. After the experiences of the 1970 s oil crises as well as macroeconomic and debt crises in many Latin American economies during the 1980s, elites in Brazil, as in other countries in the region, felt disaffected with the protectionist importsubstitution policies of the past. As described in Abreu (2004) and Kovak (2011) trade liberalization became an explicit objective of the Brazilian government, which also managed to curb protectionist interests. The implications of this for the present analysis are that tariff reductions over the 1987-1994 period of trade liberalization can be considered reasonably exogenous to industry performance and labor market outcomes, which is an important element of the identification strategy in this paper.

Although the exogeneity of trade policy changes to private sector interests is difficult to test formally, the pattern and magnitude of tariff reductions over this phase of trade liberalization is consistent with the stated policy objective of systematically reducing the level and spread of import tariffs. Figure A2 in the appendix plots the reduction in tariffs between 1987 and 1994 
against the pre-liberalization (1987) level for 31 industries. This shows that tariff cuts where overwhelmingly determined by the pre-liberalization levels in tariffs. In addition, Kovak (2011) shows that there is no relationship between pre-liberalization employment growth and sectoral tariff changes over the period 1987-1995, which renders further support to the notion that tariff reductions were as exogenous to industry performance as can be realistically hoped for in a realworld setting.

However, exogeneity arguments seem somewhat weaker for tariff changes post 1994. Figure A1 documents that the Brazilian government partially slid back on trade reforms in 1995, particular in the automobile sector, where nominal tariffs rebound from 19.9 percent in 1994 to 41 percent in 1995 and 52.4 percent in 1996. As discussed in Abreu (2004), this reversal was formally justified by the deteriorating trade balance due to rising imports and an increasingly overvalued exchange rate from 1995 onwards. However, the fact that only few industries experienced such a rebound in tariffs also suggests that resurging protectionist interests in the wake of increasing competition from abroad could have played a role. Indeed figure A3 shows that 1994-1997 tariff increases were somewhat concentrated amongst formerly highly protected industries, though the relationship does not appear to be very strong. Nonetheless we prefer using tariff changes over the 1987-1994 period for the analyses in this paper, as these are more plausibly exogenous than the subsequent tariff changes. Using tariff changes until 1994 also ensures that our results are not influenced by the internal tariff changes under the Mercosur customs union, which became effective on January 1, 1995 with the setting of the CET and the elimination of tariff and nontariff trade barriers amongst its members over a transition period (Grigoli 2011). In practice, however, our results are not significantly affected by whether we use tariff changes over 19871994 or over a slightly longer time period (such as 1987-1996).

Tariff reductions were not the only element of trade reforms in Brazil. Until 1990, non-tariff trade restrictions, such as import licenses or quotas, also played an important role, though they lost significance in the following years (Castilho, Menéndez and Sztulman 2012). While we lack the data to construct a time series of non-tariff related trade barriers by industry, there is evidence that tariff and non-tariff measures were often implemented complementarily to one another, creating a degree of tariff redundancy (see Carvalho 1992 for Brazil; see Goldberg and Pavcnik 2007 for a more general discussion). This suggests that our tariff exposure measure may partly capture the combined effect of tariff and non-tariff barriers, which ought to be kept in mind when interpreting the results. The Brazilian trade reforms of the late 1980s and 1990s did not include special or new incentives for export promotion. On the contrary, the mounting public deficit had already forced the Brazilian administration to abolish several exports subsidy schemes in the mid-1980s, prior to import tariff liberalization reforms (GATT 1993a, b; Pereira 2006).

\subsection{Women's Labor Market Outcomes}

This section turns to the evolution of economic activity and other labor market outcomes amongst Brazilian women. Despite the fact that we are mainly interested in the period of trade liberalization (1987-1994), we show trends over the past three decades to put our results into the perspective of long-term changes in women's labor market participation. Figure 1 shows trends in female labor force participation and employment for the period 1985 to 2009 - where the difference between the two trend lines shows the share of the female population that is 
unemployed. ${ }^{11}$ We view labor force participation, employment and unemployment as important and complementary indicators of women's labor market engagement. However, employment is arguably measured more reliably than the other two variables because of the empirical difficulty to distinguish unemployed (who per definition must be actively searching for employment) from non-participating individuals, where the latter includes discouraged workers no longer actively searching for a job (see Jones and Riddell 1999 for a discussion).

Figure 1: Female labor force participation and employment, 1985-2009

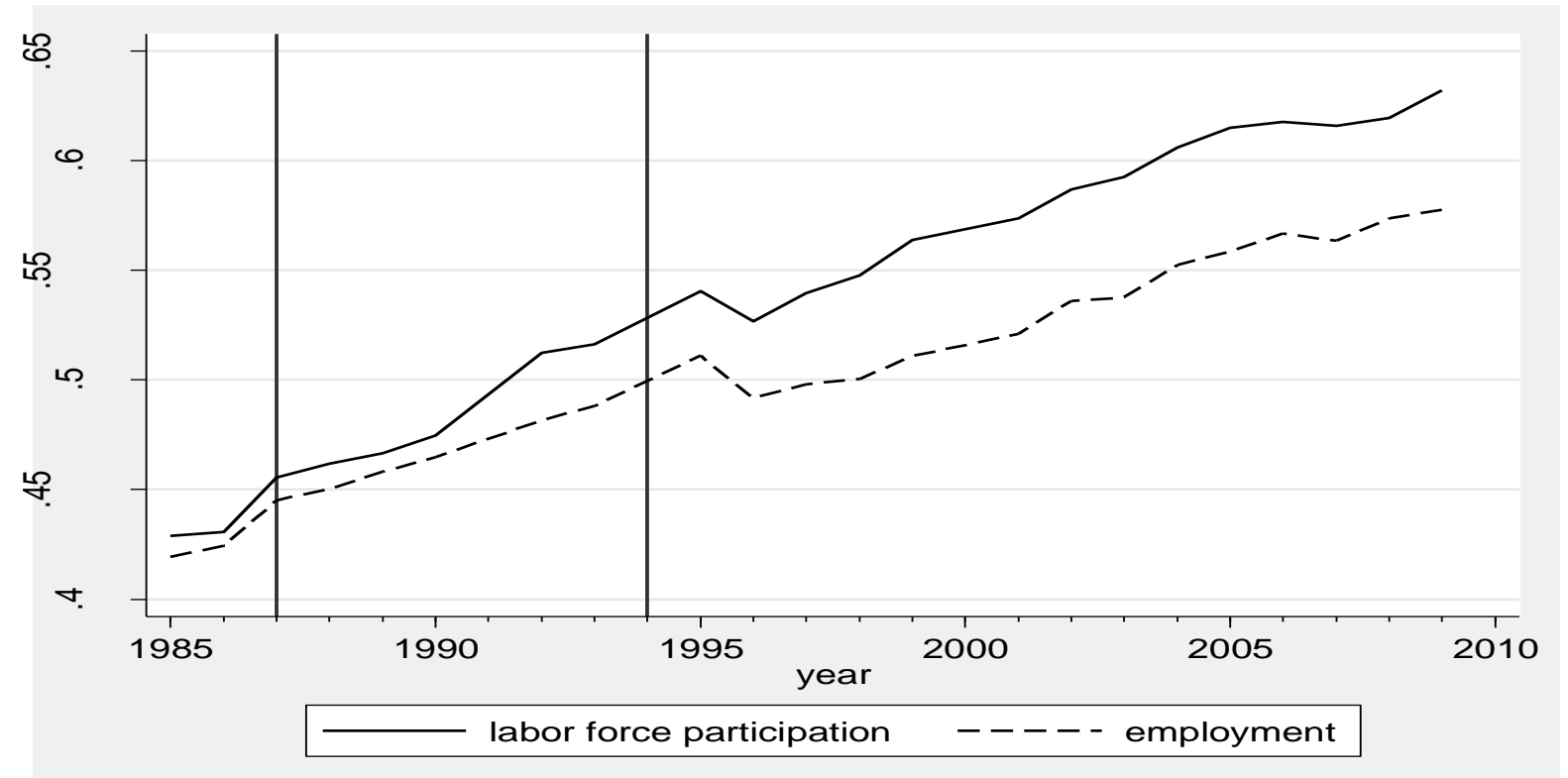

Clearly, there is a long-term trend of increasing female labor force participation over the entire period, which is consistent with secular patterns in many developing countries in Latin America, the Middle East and parts of Asia (Gaddis and Klasen 2012). The figure also shows that the increase in labor force participation of women in Brazil can be partly explained by rising female employment (the dashed line), but also by rising female unemployment (the growing gap between the dashed and the solid line). ${ }^{12}$ The two vertical lines in figure 1 mark the main period of trade liberalization considered in this paper (1987-1994). The descriptive trends show that there was an accelerated increase in female labor force participation and (to a lesser degree) female employment over the late 1980s and early 1990s, compared to the second half of the decade.

Figure 2 disaggregates the trends in economic activity by socioeconomic group. The left panel documents a strong positive correlation between education and female labor force participation. In the mid-1980s, highly education women (12+ years of education) were more than twice as likely to be in the labor force as women with low education levels (0-7 years). However, the graph also shows that the increase in labor force participation during the period of trade

\footnotetext{
${ }^{11}$ Note that all labor market participation rates in this paper are normalized on the total working age population (25-64 years). Hence the employment rate is the share of the female population working and the unemployment rate is the share of the female population unemployed. This differs from the usual concept of unemployment rates, which are normalized on the economically active population.

${ }^{12}$ Against the overall trend, there is a decline in female economic activity and employment between 1995 and 1996 (of 1-2 percentage points), which we cannot well explain, but which is consistent with ILO labor force participation estimates (ILO 2009). This was a period of positive, albeit slow economic growth. Also, to our knowledge, there were no major changes in the coverage of the PNAD data or in the survey instruments over this time.
} 
liberalization (and beyond) mainly came from women with low (0-7 years) and intermediate (8-11 years) education levels. In addition, though not shown by the graph, rising female education also contributed to the surge in female labor force participation over the entire period (see table A1 in the appendix for further descriptive statistics).

The right panel of figure 2 shows further trends by ethnic group - distinguishing between afroBrazilians (which includes the indigenous population), whites and Asians. Ethnicity is much less associated with labor force participation than education - with whites and afro-Brazilians having similar economic activity rates until the early 2000s (since then white women have seen stronger surges in participation). Only Asians women show somewhat higher activity levels over most the period - but this is a relatively small group of the total female population (which can also parly explain greater fluctuation of the estimates).

Figure 2: Female labor force participation by socioeconomic group, 1985-2009

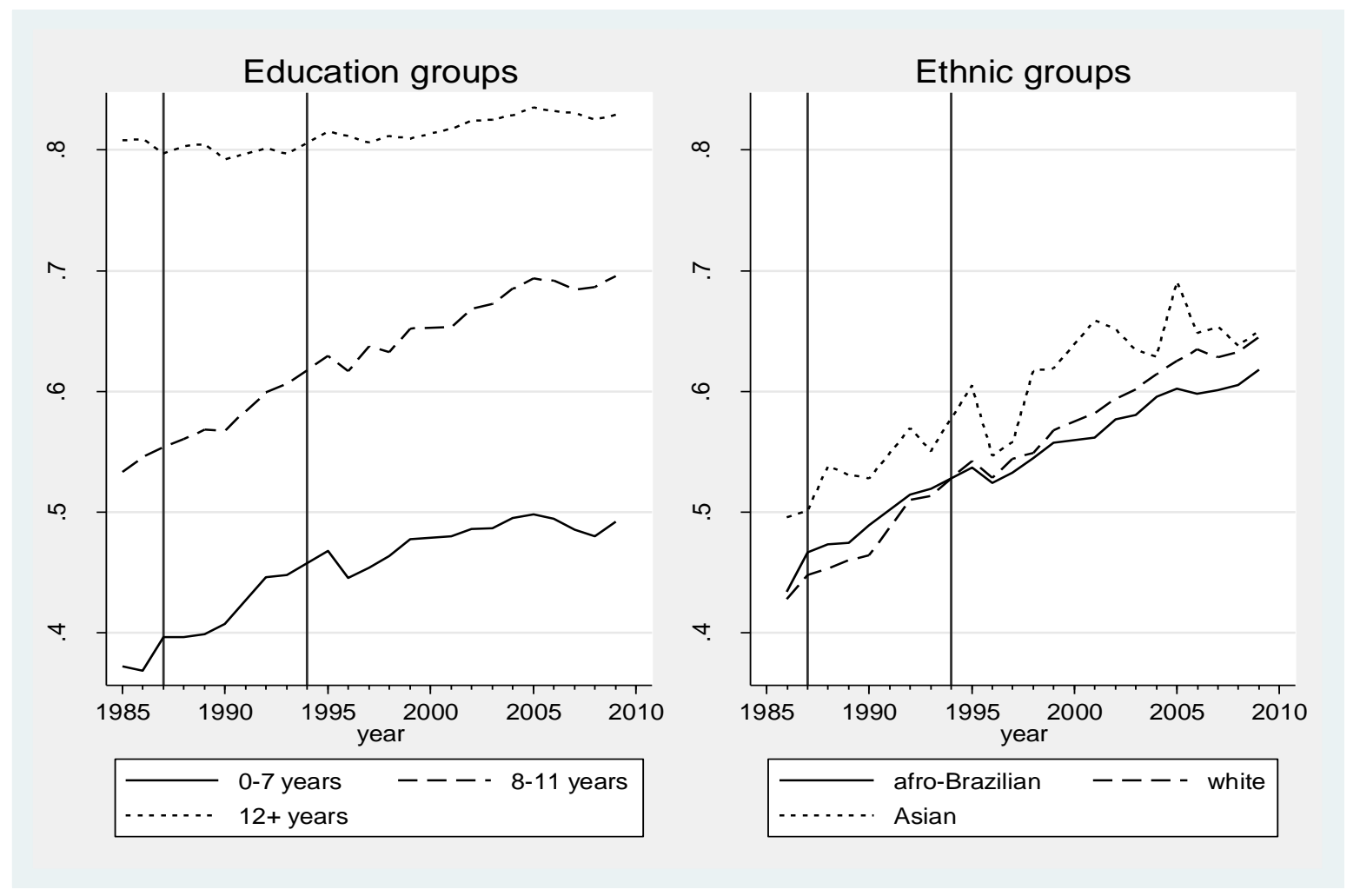

The observation that female labor force participation and employment saw an accelerated increase during the late 1980s and early 1990s (particularly amongst women with low education levels), suggests that trade liberalization might have contributed to rising female economic activity. However, one should not read too much into this simple association as there were other macroeconomic changes taking place in the Brazilian economy. The Constitutional reform of 1988 included changes in labor legislation (which reduced the flexibility of the labor market) and it has been argued that this led to an increase in informal sector employment (Bosch, Goni and Maloney 2012). Moreover, the country was hit by a recession and record inflation in 1990-1992, which could explain rising female labor force participation (see Bhalotra and Umaña-Aponte 2010 on the countercyclical natures of female labor supply). In 1994, after several failed attempts to curb inflation, the government of Brazil launched the Real Plan that introduced a new currency and brought prices under control, which again could have triggered labor market responses. The 
next section sets out to isolate the causal impact of trade reforms on female labor market outcomes, exploiting the fact that the Brazilian states were differentially exposed to tariff changes over time. Section 4.4 further addresses the potentially confounding effects of other policy changes taking place over this period, particularly capital account liberalization and increasing levels of foreign direct investment.

\section{The Effect of Trade Liberalization on Women's Labor Market Outcomes}

\subsection{Trade Protection Measure and Identification}

Following Toplova $(2007,2010)$ and Edmonds, Pavcnik and Topalova (2010) we construct a region-level time-varying measure of exposure to trade reforms (here denoted as trade protection measure - TP), which reflects geographic differences in the pre-liberalization industry composition of employment and in sectoral tariff changes over time. We compute TP separately for urban and rural areas of each federal state (here for simplicity denoted as states). In a first step we need to match the PNAD activity codes with the tariff data. Therefore we map PNAD activities to 22 broad sectors (21 tradable sectors and the non-tradable sector) based on the concordance table displayed in Ferreira, Leite and Wai-Poi (2010), but with minor adjustments. ${ }^{13}$ We then merge these sectors with the tariff data. ${ }^{14}$ In a second step we use the PNAD to estimate sector-level employment shares by state for the year preceding the tariff reforms (here 1987). These 'base-year' employment shares act as weights for the industry-level tariff changes and thus proxy for cross-sectional variation in exposure to trade reforms. ${ }^{15}$ In a third step, we compute the state-level trade exposure measure according to the following formula:

$$
T P_{s, t}=\sum_{k=1}^{K} \frac{E m p_{s, k, 1987}}{E m p_{s, 1987}} * \text { Trade }_{k, t}
$$

Where $T P_{s, t}$ is a measure of trade protection that varies across states $(s)$ and over time $(t)$. Trade Trt $_{k}$ is a measure of tariff protection of sector $k$ at time $t$ - either the effective rate of protection (our preferred specification) or nominal tariffs (as a robustness check). Note that in each case TP is scaled in such a way that a high value indicates high levels of trade protection.

Computing [1] requires a decision regarding the treatment of the non-tradable sector. There are two different approaches applied in the literature as discussed in Edmonds, Pavcnik and Topalova (2010), Cain, Hasan and Mitra (2010) and Kovak (2011). One approach is to let non-tradables enter the trade protection measure as an additional sector, with tariffs (or effective rates of protection) being assigned zero over the entire period (e.g. Topalova 2007; Kis-Katos and

\footnotetext{
${ }^{13}$ In particular we combine the sub-sectors 'processing of vegetal products' and 'meat packing, dairy industry, vegetal and other food products'; we also merge 'leather and skins' with 'footwear', and 'manufacturing of synthetic materials' with 'unclassified manufacturing'.

${ }^{14}$ In cases where our trade protection measure (ERP or nominal tariffs) is at a finer level of disaggregation, we compute a simple average at the level of the 21 tradable sectors identified above.

${ }^{15}$ In principal it would be possible to use value added shares (instead of employment shares) as weights (as in Kis-Katos and Sparrow 2011). However, Brazil's regional national accounts (contas regionais) only distinguish between three tradable sectors - agriculture, mining and manufacturing. This means that we would lose all the tariff variation between the 19 manufacturing sub-industries. We therefore prefer using employment shares as weights.
} 
Sparrow 2011). This is based on the notion that states with a large share of employment in the non-tradable sector are less affected by trade liberalization than states with a large share of the labor force employed in the tradable sectors. The second approach is to exclude the non-tradable sector from the analysis and to rescale employment shares to sum to unity over traded sectors only (e.g. Kovak 2011; Cain, Hasan and Mitra 2010). From a theoretical perspective, the latter approach is advantageous if non-tradable sector prices are strongly influenced by traded sector prices (as discussed in Kovak 2011).

One may think of these approaches as polar cases of price transmissions between the tradable and the non-tradable sectors: The first method assumes that prices in the non-tradable sector are exogenous to tradable sector prices, while the second assumes that non-tradable prices move proportionately (and immediately) with tradable sector prices. We expect reality to come out in between these two extreme cases, though the first approach appears more plausible when working with annual tariff changes (as we do here) ${ }^{16}$ while the second approach should be a better approximation of the long-term equilibrium.

While this would suggest including the non-tradable sector for the analyses in the paper, there is a second empirical consideration that determines the choice between the two trade exposure measures. In particular the measure including non-tradables is mechanically affected by the size of the non-tradable sector, which can potentially confound the estimates if the initial size of the non-tradable sector has an impact on subsequent changes in female employment outcomes. Consider that our tariff protection measure is effectively an interaction of the base-year (1987) employment composition at the state-level and changes in sectoral tariffs over time. While we can purge time-invariant regional heterogeneity and nationwide secular trends using state and time fixed effects, we may still obtain biased estimates if there are unobserved state-specific timevarying determinants of female labor market outcomes correlated with both the state's initial employment composition and changes in national tariffs. This is more likely to be a problem if $T P$ includes the non-tradable sector, because non-tradable sector 'tariffs' do not change over time (effectively being assigned zero) so that the portion of the variation in $T P$ that is due to the nontradable sector only mirrors differences in the initial employment shares.

Comparing the index including non-tradables $\left(T P^{i n N T}, \mathrm{~K}=22\right)$ with a version of the same index excluding non-tradables ( $T P^{e x N T}, \mathrm{~K}=21$ ) confirms that the former is indeed strongly affected by the prevalence of employment in the non-tradable sectors. While both trade protection measures show a momentous decline in tariff protection between 1987 and 1994 (average $T P^{e x N T}$ declined from 0.56 to 0.07 , while $T P^{i n N T}$ fell from 0.23 to 0.02 ), the measure including non-tradables has considerably lower absolute values of protection in any given year because it assigns zero protection to the large service sector. Moreover, the two measures differ regarding the geographic pattern of trade protection prior to liberalization. In 1987, the measure based on tradable sectors only $\left(T P^{e x N T}\right.$ ) shows the highest levels of tariff protection for the metropolitan areas of Sao Paolo, Rio de Janeiro and Rio Grande do Sul, traditionally important industrial centers in Southeastern Brazil and home to much of the country's car industry, as well as for the urban areas of Santa Catarina and Ceará, which host a large share of the textile industry. $T P^{i n N T}$, on the other hand, indicates that Brazil's rural areas were the most protected regions in 1987, due to a large

\footnotetext{
${ }^{16}$ In the short-term, prices and wages in the non-tradable sector are likely to be sticky - especially towards a necessary downward adjustment.
} 
agricultural sector (which also benefitted from significant protection prior to liberalization) and a comparatively small fraction of the population employed in the service sectors (non-tradable). In light of these differences we prefer to use an instrumental variable approach as is further described below (though we also show the results for standard fixed effects estimations using $T P^{i n N T}$ and $\left.T P^{e x N T}\right)$.

\subsection{Empirical Framework}

We estimate the reduced-form relationship between trade protection and female labor market outcomes using two different data constructs. First, we aggregate all household data to the state level, to construct a state level panel dataset and estimate the following baseline specification:

$$
y_{s, t}=\alpha+\beta T P_{s, t-L}+\gamma X_{s, t}+\mu_{s}+\delta_{t}+\varepsilon_{s, t}
$$

Where $y_{\mathrm{s}, \mathrm{t}}$ is a state-level $(s)$ outcome in a given year $(t)$ - e.g. the female labor force participation rate. The other outcome variables we consider are the share of women employed and unemployed (always referring to women aged 25-64 years). By normalizing all variables on the state's total female population (rather than on the female labor force - as it is conventionally the case for official unemployment rates) we ensure that variation in our dependent variables mainly reflect changes in the enumerator. ${ }^{17}$

$T P$ is our trade protection measure, lagged either one year $(\mathrm{L}=1)$ or two years $(\mathrm{L}=2)$, and $\beta$ is the parameter estimate of interest. The lags allow for the fact that tariff changes will not affect regional employment outcomes immediately, but with some delay. To deal with ambiguity regarding the treatment of the non-tradable sector and to explore the robustness of our results, we estimate three different versions of [2]. First, we include the non-tradable sector in $T P$ (as in KisKatos and Sparrow 2011), though we view the results with caution as our estimate of $\beta$ would be biased if changes in female labor market outcomes are related to the initial size of the nontradable sector. Second, we exclude the non-tradable sector from TP (as in Kovak 2011; Cain, Hasan and Mitra 2010). We believe, however, that the regional exposure to tariff reductions does vary to some degree with the relative size of the nontradable sector, so in our preferred specification, we use the exogenous $T P^{e x N T}$ as an instrument for $T P^{i n N T}$ (as in Topalova 2007, 2010; Edmonds, Pavcnik and Topalova 2010). As described above, this is to accommodate that regions with a large share of employment in the non-tradable sector are initially less affected by trade policy changes than regions with only a small non-tradable sector (which renders $T P^{i n N T}$ the preferable measure of exposure to tariff changes). At the same time it addresses the potential endogeneity of $T P^{i n N T}$ - caused by the plausible correlation between the size of the non-tradable sector in the base period and subsequent changes in female labor force participation - by using $T P^{e x N T}$, which is not influenced by the size of the non-tradable sector but highly correlated to $T P^{i n N T}$, as an instrument. Finally, $X$ is a vector of time-varying control variables at the state level (particularly changes in female education). All specifications include state fixed effects $\left(\mu_{s}\right)$ to control for time-invariant unobserved regional heterogeneity, while year fixed effects $\left(\delta_{t}\right)$ control

\footnotetext{
${ }^{17}$ Changes in the denominator would still be possible if there were strong fluctuations in the female population of each state, e.g. due to migration between federal states. However, given that the analysis here focuses on short-time effects at the level of fairly large geographical areas substantial population shifts due to migration seem unlikely.
} 
for macroeconomic factors (such as the business cycle) and other trends affecting the country as a whole. Standard errors are always clustered at the state-level and the regressions are weighted by the number of women in the state in the base year.

The model in [2] uses a panel data set up and is identified on within-state variation in trade protection. However, this comes at the expense of losing the individual variation in the data because we aggregate information on 60,000 to 75,000 women at the level of 46 states. To maintain greater flexibility in controlling for individual and family-level characteristics, we also estimate an individual-level model on the pooled sample:

$$
y_{i, s, t}=\alpha+\beta T P_{s, t-L}+\gamma X_{i, s, t}+\mu_{s}+\delta_{t}+\varepsilon_{i, s, t}
$$

Where $y_{\mathrm{i}, \mathrm{s}, \mathrm{t}}$ is an employment outcome of woman $(i)$ in a state $(s)$ in a given year $(\mathrm{t})$ and $X_{\mathrm{i}, \mathrm{s}, \mathrm{t}}$ is a vector of individual level control variables (in particular age, age squared, education, number of children and ethnicity). $\mu_{s}$ is a state fixed effect which captures unobserved regional heterogeneity. We also estimate specifications of [3] where we restrict the sample to married women and include further controls for the labor market status of the husband. The model in [3] is estimated using a (weighted) linear probability model. While a binary choice model could also be estimated, we prefer the linear probability for ease of interpretation and comparison with the state-level estimates of equation [2]. As in the context of grouped data analysis, standard errors are clustered at the level of states.

\subsection{The Impact of Trade Liberalization on Female Labor Market Outcomes}

Table 1 shows the estimation results for equations [2] (the state-level estimates, in panel A) and [3] (the individual level estimates, in panel B) on three different measures of women's labor market outcomes. Both equations are estimated with trade protection lagged either one year or two years, so that we look at labor market outcomes for the period 1988-1995 or 1989-1996. For each outcome, the table shows the effect of trade protection with the non-traded sector included (FE-inNT), excluded (FE-exNT), or the latter used as instrument for the former (TSLS). Table A2 in the appendix shows the results for the first stage, documenting that there is a strong positive association between $T P^{i n N T}$ and $T P^{e x N T}$.

The FE-inNT estimates show that declining trade protection is associated with growing female labor force participation and employment, and declining unemployment, both with a one-year and a two-year lag. Excluding the non-tradable sector, estimates FE-exNT show the same two-year lagged effects, though smaller, while the first-year lagged effect is of opposite sign and no longer statistically significant. 
Table 1: Trade protection and female labor market outcomes

\begin{tabular}{|c|c|c|c|c|c|c|c|c|c|}
\hline \multicolumn{10}{|c|}{$\begin{array}{l}\text { A: Grouped data estimations (state panel) } \\
\text { Controls: Education }\end{array}$} \\
\hline & \multicolumn{3}{|c|}{$\underline{\text { Labor force participation }}$} & \multicolumn{3}{|c|}{$\underline{\text { Employment }}$} & \multicolumn{3}{|c|}{ Unemployment } \\
\hline & FE-inNT & FE-exNT & TSLS & FE-inNT & FE-exNT & TSLS & FE-inNT & FE-exNT & TSLS \\
\hline TP at $\mathrm{t}-1$ & $\begin{array}{c}-0.143 * * * \\
(0.049)\end{array}$ & $\begin{array}{c}0.041 \\
(0.057)\end{array}$ & $\begin{array}{c}0.131 \\
(0.200)\end{array}$ & $\begin{array}{c}-0.178 * * * \\
(0.053)\end{array}$ & $\begin{array}{c}0.065 \\
(0.068)\end{array}$ & $\begin{array}{c}0.208 \\
(0.253)\end{array}$ & $\begin{array}{c}0.035 * * * \\
(0.009)\end{array}$ & $\begin{array}{l}-0.024 \\
(0.015)\end{array}$ & $\begin{array}{l}-0.078 \\
(0.066)\end{array}$ \\
\hline $\mathrm{TP}$ at $\mathrm{t}-2$ & $\begin{array}{c}-0.183 * * * \\
(0.047)\end{array}$ & $\begin{array}{c}-0.099 * * * \\
(0.035)\end{array}$ & $\begin{array}{c}-0.337 * * * \\
(0.128)\end{array}$ & $\begin{array}{l}-0.248 * * * \\
(0.047)\end{array}$ & $\begin{array}{c}-0.098 * * \\
(0.040)\end{array}$ & $\begin{array}{c}-0.335^{* * *} \\
(0.115)\end{array}$ & $\begin{array}{c}0.065 * * * \\
(0.010)\end{array}$ & $\begin{array}{l}-0.001 \\
(0.012)\end{array}$ & $\begin{array}{l}-0.003 \\
(0.039)\end{array}$ \\
\hline $\mathrm{N}$ & 276 & 276 & 276 & 276 & 276 & 276 & 276 & 276 & 276 \\
\hline
\end{tabular}

B: Individual-level estimations (pooled sample)

Controls: Education, age, age squared, children, ethnicity

Labor force participation

Employment

Unemployment

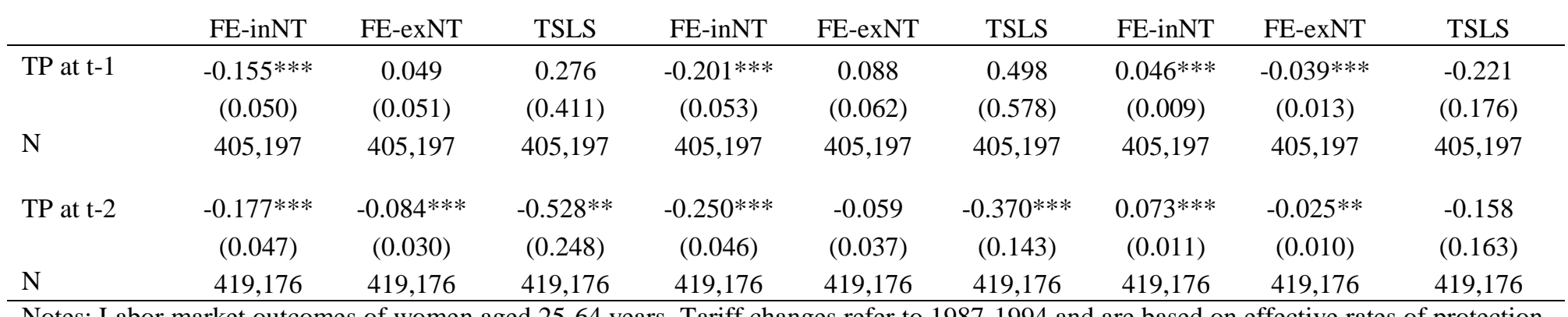

Notes: Labor market outcomes of women aged 25-64 years. Tariff changes refer to 1987-1994 and are based on effective rates of protection. All estimations control for state-fixed effects and year effects. Standard errors clustered at the state-level, for 46 states, are reported in parentheses. Grouped-data estimations are weighted by states' number of females (in 1987); individual-level estimations are weighted by sampling weights. $* * * \mathrm{p}<0.01, * * \mathrm{p}<0.05, * \mathrm{p}<0.1$ 
Our explanation for this divergence is that with a one-year lag, a larger reduction in $T P^{i n N T}$ is associated with a faster increase in female employment at the state level. However, states with a smaller initial employment share of the non-tradable sector also see a larger reduction in $T P^{i n N T}$, and since these are most likely also the states with lower initial female labor force participation where one would expect female labor force participation to grow faster, there would be a negative coefficient on $T P^{i n N T}$ even in the absence of an effect of tariff reductions. Therefore, the FE-inNT estimates are downward biased, and the TSLS estimates show no effect of trade liberalization in the first year.

With a two-year lag, however, the TSLS estimations do show a stronger increase in female labor force participation in states with greater reductions in trade protection. With an average decline in trade protection of 0.21 (over the entire period 1987-1994), this corresponds to an increase in the female labor force participation rate of about 7 percentage points. The effect on participation is larger in the pooled individual-level estimation, where we also control for the number of children, age, and ethnicity. And finally, we find that the effect on participation is entirely accounted for by rising employment of women, as there is no significant impact on unemployment. In what follows, we focus on the TSLS estimations, our preferred specification (results for the FE-inNT and FE-exNT specifications are available upon request).

\subsection{Robustness Analysis}

A potential source of bias in our estimates from equation [2] is that some unobserved statespecific changes in female labor supply maybe correlated with changes in the state's trade protection. This would be the case if such unobserved changes were related to the initial sector composition of the region's employment. The endogeneity of the initial share of the non-tradable sector is addressed in the TSLS estimations, but we also estimate the model allowing for a different trend in female labor market outcomes across states with different initial employment shares in agriculture, mining, manufacturing industry, construction, trade, transport, and social, domestic, and other services. Results for the grouped estimations are shown in table 2, and show a slightly smaller effect on female labor force participation, consisting of a larger impact on employment and a small off-setting impact on unemployment. As before, the effects appear only with a 2-year lag, while there are no significant impacts in the first year after tariff reductions.

Table 2: Trade protection and female labor market outcomes with additional controls

\begin{tabular}{|c|c|c|c|}
\hline \multicolumn{4}{|c|}{ Grouped data estimations (state panel): controlling for initial sector shares $x$ linear time trend } \\
\hline & Labor force participation & Employment & Unemployment \\
\hline \multirow[t]{2}{*}{ TP at $\mathrm{t}-1$} & -0.077 & -0.079 & 0.002 \\
\hline & $(0.065)$ & $(0.073)$ & $(0.018)$ \\
\hline $\mathrm{N}$ & 276 & 276 & 276 \\
\hline \multirow[t]{2}{*}{$\mathrm{TP}$ at $\mathrm{t}-2$} & $-0.307 * * *$ & $-0.362 * * *$ & $0.055^{* * *}$ \\
\hline & $(0.067)$ & $(0.063)$ & $(0.018)$ \\
\hline $\mathrm{N}$ & 276 & 276 & 276 \\
\hline
\end{tabular}

Notes: Labor market outcomes of women aged 25-64 years. Tariff changes refer to 1987-1994 and are based on effective rates of protection. TSLS estimates with TP-exNT as instrument for TP-inNT, all estimations control for state-fixed effects, education, and year effects. Standard errors clustered at the state level, for 46 states, are reported in parentheses. Estimations are weighted by states' number of females (in 1987). *** $\mathrm{p}<0.01, * * \mathrm{p}<0.05, * \mathrm{p}<0.1$ 
Though the effect of trade protection is not driven by the initial employment structure and the tariff reductions were exogenous at least until 1994, the estimates may still be driven partly by foreign direct investment (FDI). Between 1987 and 1992 the Brazilian government took a series of steps towards capital account convertibility and liberalization, which included the creation of foreign capital investment companies and funds, stock and bond portfolios (Goldfajn and Minella 2005). As a result, the stock of FDI in Brazilian industry, which was rather constant in the early 1990s, picked up significantly after 1992 (Muendler 2003; see also Appendix figure A3). ${ }^{18}$ Since there is some previous research showing an effect of FDI on women's employment, rising capital inflows from abroad could also have affected female labor market outcomes (see Cooray, Gaddis, and Wacker 2012). Moreover, FDI flows could have been related to trade reforms, which would lead to a correlation between tariff changes and foreign investment at the sector level and an overestimation of the pure trade effect. To rule out the effect of FDI, we run our estimations for trade protection between 1987 and 1990 only, corresponding to women's labor force participation in the period up to 1992. The results in table 3 are very similar to the main results, with a somewhat smaller impact on labor force participation, as we now see a decline in unemployment as well as a rise in employment following a decline in trade protection.

Table 3: Trade protection and female labor market outcomes until 1992

\begin{tabular}{|c|c|c|c|}
\hline \multicolumn{4}{|c|}{ Grouped data estimations (state panel): trade protection 1987-1990 } \\
\hline & Labor force participation & Employment & Unemployment \\
\hline \multirow[t]{2}{*}{ TP at $\mathrm{t}-1$} & -0.058 & -0.071 & 0.014 \\
\hline & $(0.054)$ & $(0.056)$ & $(0.010)$ \\
\hline $\mathrm{N}$ & 138 & 138 & 138 \\
\hline \multirow[t]{2}{*}{$\mathrm{TP}$ at $\mathrm{t}-2$} & $-0.239 * * *$ & $-0.331 * * *$ & $0.092 * * *$ \\
\hline & $(0.074)$ & $(0.081)$ & $(0.028)$ \\
\hline $\mathrm{N}$ & 138 & 138 & 138 \\
\hline \multicolumn{4}{|c|}{$\begin{array}{l}\text { Notes: Labor market outcomes of women aged } 25-64 \text { years. Tariff changes refer to } 1987-1990 \text { and } \\
\text { are based on effective rates of protection. TSLS estimates with TP-exNT as instrument for TP-inNT, } \\
\text { all estimations control for state-fixed effects, education, and year effects. Standard errors clustered at } \\
\text { the state level, for } 46 \text { states, are reported in parentheses. Estimations are weighted by states' number } \\
\text { of females (in 1987). *** p<0.01, ** p<0.05, }{ }^{*}<0.1\end{array}$} \\
\hline
\end{tabular}

Finally we also repeat all the estimations using nominal tariffs instead of effective rates of protection. While do we believe that the effective rate of protection is the preferable measure of trade protection, nominal tariffs have been used in much of the existing empirical literatures (e.g. Topalova 2007, 2010; Edmonds, Pavcnik and Topalova 2010) and allow testing whether our results also hold with an alternative measure of trade protection. The results using nominal tariffs (not shown but available on request) come out very similar to those using effective rates of protection, though the significance levels are slightly weaker. In sum, the results in this section confirm that our basic findings are robust to the inclusion of additional controls for states' initial employment distribution, different time periods used in the estimations and the use of an alternative measure of tariff protection.

\footnotetext{
${ }^{18}$ Part of the increases in foreign direct investment after 1995 was related to privatization. However, for the period considered in this study (1987-1994) privatization does not seem to play a major role (Goldfajn and Minella 2005). Similarly, Pinheiro (2002) argues that "until 1996 the role of privatization in Brazil's macroeconomic policy was essentially that of signaling commitment to reducing the size of the state and implementing structural reforms".
} 


\subsection{Trade Protection Effects across Socioeconomic Groups}

The previous sections have demonstrated that states with greater exposure to trade liberalization experienced faster increases in female labor force participation and employment and that this effect is robust to potential biases. This section seeks to explore which socioeconomic groups responded strongest to trade reforms. In particular, we look at the effect of trade protection on labor market outcomes of women with different education levels and across different ethnic groups. First, trade protection is interacted with indicators for having mid-level education (8 to 11 years) or high education (at least 12 years), where the latter corresponds to the high-skilled segment of the labor force. ${ }^{19}$ The results are shown in the first three columns of table 4 . Second, trade protection is interacted with indicators for being white or Asian, where the reference group consists of afro-Brazilians. These results are shown in the last three columns of table 4. All estimations take the two-year lagged value of trade protection.

Table 4: Effect of trade protection across socio-economic groups

\begin{tabular}{|c|c|c|c|c|c|c|}
\hline \multicolumn{7}{|c|}{$\begin{array}{l}\text { Individual-level estimations (pooled sample) } \\
\text { Controls: Education, age, age squared, children, ethnicity }\end{array}$} \\
\hline & Labor force & Employed & Unemployed & Labor force & Employed & Unemployed \\
\hline \multirow[t]{2}{*}{ TP at $\mathrm{t}-2$} & $-0.318 * * *$ & $-0.366 * * *$ & $0.048 * *$ & $-0.224 * * *$ & $-0.264 * * *$ & $0.040 *$ \\
\hline & $(0.066)$ & $(0.065)$ & $(0.021)$ & $(0.072)$ & $(0.070)$ & $(0.024)$ \\
\hline \multirow[t]{2}{*}{$\mathrm{TP}$ at $\mathrm{t}-2 *$ mid-edu } & $-0.111 * * *$ & $-0.061 *$ & $-0.049 * * *$ & & & \\
\hline & $(0.033)$ & $(0.034)$ & $(0.015)$ & & & \\
\hline \multirow[t]{2}{*}{ TP at $\mathrm{t}-2 *$ high-edu } & $0.128 * * *$ & $0.092 * *$ & $0.035 * *$ & & & \\
\hline & $(0.037)$ & $(0.037)$ & $(0.018)$ & & & \\
\hline \multirow[t]{2}{*}{ TP at $\mathrm{t}-2 *$ white } & & & & $-0.254 * * *$ & $-0.265 * * *$ & 0.011 \\
\hline & & & & $(0.036)$ & $(0.039)$ & $(0.010)$ \\
\hline \multirow[t]{2}{*}{ TP at $\mathrm{t}-2 *$ Asian } & & & & -0.042 & -0.072 & $0.030 * *$ \\
\hline & & & & $(0.080)$ & $(0.074)$ & $(0.014)$ \\
\hline $\mathrm{N}$ & 419,176 & 419,176 & 419,176 & 419,176 & 419,176 & 419,176 \\
\hline
\end{tabular}

Notes: Labor market outcomes of women aged 25-64 years. Tariff changes refer to 1987-1994 and are based on effective rates of protection. TSLS estimates with TP-exNT as instrument for TP-inNT, all estimations control for state-fixed effects, and year effects, and for different trends by states' initial sectoral employment shares. Standard errors clustered at the state-level for 46 states, are reported in parentheses. Estimations are weighted by sampling weights. *** $\mathrm{p}<0.01, * * \mathrm{p}<0.05, * \mathrm{p}<0.1$

The first three columns show that falling trade protection increases labor force participation and employment of women with low (reference group), medium, and high education, but the effect is largest for low-skilled and especially medium-skilled women. This is not surprising given the employment shifts from skilled to unskilled labor intensive sectors that resulted from trade liberalization (see Gonzaga, Menezes-Filho and Terra 2006; Ferreira, Leite and Wai-Poi 2010). A further explanation could be that the earnings or jobs of husbands of highly educated women were less affected by trade liberalization or that these couples can explore alternative means to smooth consumption in times of economic uncertainty (e.g. drawing on savings or credit markets). Hence, if a negative income effect is driving the impact of liberalization, labor force participation should indeed increase less among highly educated women. We further explore these mechanisms in the next section.

\footnotetext{
${ }^{19}$ A similar definition of skilled work is used in Ferreira, Leite and Wai-Poi (2010).
} 
Across ethnic groups, we find that white women's participation rate increases twice as much with trade liberalization compared to the other groups. This is somewhat surprising as white and especially Asian women are also more highly educated. It suggests that the demand side plays a role in rising female employment, with increasing labor demand in certain low-skilled activities, and potentially discrimination favoring white women. This would then also imply that declining discrimination in the labor market is not the main channel through which liberalization increases female labor force participation: if employers were induced to discriminate less between men and women, they should also be induced to discriminate less between whites and non-whites, and we would expect seeing a stronger increase in participation amongst minority groups.

\section{Mechanisms}

\subsection{Between-Sector Changes}

This section now further investigates some of the potential mechanisms that could drive the reduced-form results of the previous section. Earlier studies for Brazil have demonstrated that trade liberalization has been associated with significant employment flows across sectors (Ferreira, Leite and Wai-Poi 2010, Menezes-Filho and Muendler 2011), but have not considered any gender-specific aspects of this reallocation. As discussed in section 3, structural changes in production and employment can have strong implications for women's employment if male and female labor are imperfect substitutes or if social stigmatization or gender-specific preferences prevent women from entering certain sectors of the economy. To shed more light on this channel, we decompose the 1987-1995 change in the female share of total employment into changes across and within sectors, using the following equation:

$$
\Delta S^{f}=\sum_{k=1}^{K} \Delta S_{k}^{f} \bar{P}_{k}+\sum_{k=1}^{K} \Delta P_{k} \bar{S}_{k}^{f}
$$

where $S_{k}^{f}$ is the female share of employment in industry $k$ and $P_{k}$ is industry $k$ 's share of total employment; a bar indicates the average of 1987 and 1995. The first term on the right hand side is the within-industry contribution, which is positive if the female employment shares within industries increase, on average. The second right hand side term is the between-industry contribution to the total change, which is positive if the average female intensity in expanding sectors is higher than the average female intensity in declining sectors. The decomposition results (for $\mathrm{K}=29$ sectors) are shown in appendix table A3.

Between 1987 and 1995, the female share of total employment increased from 34.6 to 39 percent and we find that within-sector changes and between-sector shifts contributed equally to overall workforce feminization (although this always varies with the level of aggregation). Agriculture and most tradable manufacturing sectors have a somewhat below-average female intensity in 1987, which rises over time while their employment shares decrease. Thus, the tradable sector contributed positively to within-sector feminization, mainly due to agriculture and food processing, but has a negative between-component. The non-tradable sector, which increased from 62 to 68 percent of total employment, had an above-average and increasing female intensity. The female employment share was highest in trade, social services, and domestic services. The increased feminization within these services sectors and especially the expansion of these sectors (in particular domestic services) contributed most to Brazil's workforce feminization. 
The between-sector changes that we find are in line with sectoral reallocations induced by trade liberalization, but also with more general structural change. To better understand the role of trade policy changes we further estimate the effect of trade protection on male and female employment in particular sectors. In states with faster reductions in trade protection, we see a larger shift from agricultural employment to trade and other services among women (table 5, panel A), and continued faster growth of employment in trade and other services in the second year after tariff reductions. For men (panel B), employment in trade and other services also increases faster with greater tariff reductions, while we see a larger decline in manufacturing employment in the first and second year after trade reforms.

Taken together, our findings and the results from previous studies (e.g. Chamon 1998, World Bank 2002, Menezes-Filho and Muendler 2011) support the view that trade liberalization-induced labor reallocations contributed to workforce feminization, especially the shift from manufacturing to services. This is in line with Goldin's (1995) notion that structural transformation from industry to services increases women's economic activity. Contrarily, we do not find evidence for the model developed in Sauré and Zoabi (2009), according to which female labor force participation declines if labor reallocates towards those sectors that are initially female labor intensive. Still, there was also substantial workforce feminization within virtually all industries, suggesting that other mechanisms have also played a role in the impact of trade liberalization on female labor force participation and that these factors are drawing women even into traditionally male-dominated sectors. ${ }^{20}$ We now turn to the role of income effects, which could potentially explain the within sector feminization of the workforce.

Table 5: Trade protection and female and male employment by sector

\begin{tabular}{|c|c|c|c|c|c|}
\hline \multicolumn{6}{|c|}{ A: Grouped data estimations (state panel) - female employment by sector } \\
\hline & Agriculture & Manufacturing & Construction & Trade & Other Services \\
\hline TP at $\mathrm{t}-1$ & $\begin{array}{c}0.587 * * \\
(0.288)\end{array}$ & $\begin{array}{c}0.025 \\
(0.046)\end{array}$ & $\begin{array}{c}0.023 \\
(0.022)\end{array}$ & $\begin{array}{c}-0.190 * * * \\
(0.056)\end{array}$ & $\begin{array}{c}-0.236 * * * \\
(0.077)\end{array}$ \\
\hline $\mathrm{N}$ & 276 & 276 & 276 & 276 & 276 \\
\hline TP at $\mathrm{t}-2$ & $\begin{array}{l}-0.051 \\
(0.090)\end{array}$ & $\begin{array}{l}-0.014 \\
(0.033)\end{array}$ & $\begin{array}{c}0.002 \\
(0.006)\end{array}$ & $\begin{array}{c}-0.154^{* * * *} \\
(0.056)\end{array}$ & $\begin{array}{c}-0.117 * * \\
(0.054)\end{array}$ \\
\hline $\mathrm{N}$ & 276 & 276 & 276 & 276 & 276 \\
\hline
\end{tabular}

B: Grouped data estimations (state panel) - male employment by sector

\begin{tabular}{lccccc} 
& Agriculture & Manufacturing & Construction & Trade & Other Services \\
\hline TP at t-1 & 0.175 & $0.564^{* * *}$ & -0.266 & $-0.151^{*}$ & $-0.342^{* * *}$ \\
& $(0.228)$ & $(0.142)$ & $(0.168)$ & $(0.078)$ & $(0.105)$ \\
$\mathrm{N}$ & 276 & 276 & 276 & 276 & 276 \\
& & & & & \\
TP at t-2 & -0.151 & $0.282^{* * *}$ & 0.027 & $-0.119^{* * *}$ & $-0.120^{*}$ \\
& $(0.092)$ & $(0.107)$ & $(0.068)$ & $(0.044)$ & $(0.063)$ \\
$\mathrm{N}$ & 276 & 276 & 276 & 276 & 276 \\
\hline
\end{tabular}

Notes: Employment share of women and men aged 25-64 years by industry. Tariff changes refer to 1987-1994 and are based on effective rates of protection. TSLS estimates with TP-exNT as instrument for TP-inNT, all estimations control for state-fixed effects, education, and year effects, and are weighted by the state's female or male population (in 1987). Standard errors clustered at the state-level, for 46 states, are reported in parentheses. $* * * \mathrm{p}<0.01, * * \mathrm{p}<0.05, * \mathrm{p}<0.1$

\footnotetext{
${ }^{20}$ Of course, the level of industrial disaggregation also plays a role and we cannot rule out that women are only entering specific sub-sectors (or occupations) of the broadly defined sectors considered here.
} 


\subsection{Income Effects}

Since women's labor force participation decision is well known to be a function of their husband's earnings (e.g. Blau and Kahn 2007), the employment and earnings of men can be an important channel for the effect of trade liberalization. Brazil's trade liberalization was associated with significantly more transitions into unemployment and out of the labor force (Menezes-Filho and Muendler 2011), and this mostly affected the predominantly male manufacturing sector workers. Rising female participation may therefore be a response to increasing unemployment among men, or to overall increasing insecurity in the labor market. In support of this channel, Fernandes and Felício (2005) show that wives are more likely to enter the labor force after their husbands have become unemployed, using data from Brazil's monthly employment survey (PME) for the years 1985, 1993, and 1999 (which includes the period of trade reforms). ${ }^{21}$

In table 6 we show the TSLS estimation results of equation [2] with men's labor market outcomes as dependent variable. While male labor force participation and employment are not affected, the last columns shows that states with greater reductions in trade protection experienced greater increases in male unemployment, with a one-year lag. This confirms previous findings, even though we are not able to control for individual employment histories, employer characteristics, etc.

Table 6: Trade liberalization and men's labor market outcomes

\begin{tabular}{|c|c|c|c|}
\hline \multicolumn{4}{|c|}{$\begin{array}{l}\text { Grouped data estimations (state panel) } \\
\text { Controls: Education }\end{array}$} \\
\hline & Labor force participation & Employment & Unemployment \\
\hline \multirow[t]{2}{*}{ TP at $\mathrm{t}-1$} & -0.118 & -0.020 & $-0.098 * *$ \\
\hline & $(0.077)$ & $(0.082)$ & $(0.041)$ \\
\hline $\mathrm{N}$ & 276 & 276 & 276 \\
\hline \multirow[t]{2}{*}{$\mathrm{TP}$ at $\mathrm{t}-2$} & -0.074 & -0.082 & 0.008 \\
\hline & $(0.067)$ & $(0.073)$ & $(0.030)$ \\
\hline $\mathrm{N}$ & 276 & 276 & 276 \\
\hline \multicolumn{4}{|c|}{$\begin{array}{l}\text { Notes: Labor market outcomes of men aged } 25-64 \text { years. Tariff changes refer to } 1987-1994 \text { and are } \\
\text { based on effective rates of protection. TSLS estimates with TP-exNT as instrument for TP-inNT, all } \\
\text { estimations control for state-fixed effects and year effects. Standard errors clustered at the state-level, } \\
\text { for } 46 \text { states, are reported in parentheses. Estimations are weighted by states' number of males (in } \\
1987) \text {. *** } p<0.01, * * p<0.05, * p<0.1\end{array}$} \\
\hline
\end{tabular}

The next step is to investigate whether husbands' unemployment indeed increases women's labor supply, and whether the effect of trade liberalization changes once this effect is controlled for. For this we use the pooled individual-level data, and restrict the sample to married women. ${ }^{22}$ Restricting the sample as such does not change the main results: comparing panel B of table 1 and the first three columns of table 7 , we still see a negative coefficient of two-year lagged trade protection, although it is a little bit smaller for the sample of married women only. The last three columns add an indicator for whether the woman's spouse is currently unemployed, and the family non-labor income, which have the expected effects on women's participation. ${ }^{23}$ Women

\footnotetext{
${ }^{21}$ Unlike the PNAD, the PME data are representative for metropolitan Brazil only.

${ }^{22}$ Marital status is not actually available in the PNAD data, so we restrict the sample to women who are the spouse of the household head and women who are household head and have a spouse present in the household.

${ }^{23}$ We find similar results when we control for husbands' earnings.
} 
are more likely to participate in the labor market, both in employment and unemployment, when their husbands are unemployed. However, the coefficient of our trade protection measure is hardly affected, which casts some doubt on whether this is actually a transmission channel or rather an additional female labor force participation enhancing effect, and the effects are quantitatively too small to explain much of the increase in female economic activity.

In light of these results we cannot firmly conclude that unemployment of husbands was a main channel for the effect of liberalization on wives' labor force participation, but we clearly see that unemployment among men is associated with more women entering the labor force. Given the cross-sectional nature of the data, we cannot measure the labor market transitions of either spouse, so we may not be able to adequately capture the dynamics of this effect. Husband's unemployment spells might be too short to show up in the PNAD data, while even short spells can induce wives to (look for) work because of the increased insecurity in the labor market. Similarly, women could respond preemptively to greater volatility in regional labor markets even if their husbands are not (yet) suffering job or earnings losses. This could also explain why the regional trade exposure measure is not substantially affected by controlling for husband's unemployment and family non-labor income.

Table 7: Trade liberalization and married women's labor market outcomes

Individual-level estimations for married women (pooled sample)

Controls: Education, age, age squared, children, ethnicity

\begin{tabular}{lcccccc}
\hline & Labor force & Employed & Unemployed & Labor force & Employed & Unemployed \\
\hline TP at t-2 & $-0.471^{* *}$ & $-0.319^{* *}$ & -0.152 & $-0.466^{* *}$ & $-0.316^{*}$ & -0.150 \\
& $(0.238)$ & $(0.162)$ & $(0.167)$ & $(0.233)$ & $(0.163)$ & $(0.163)$ \\
Husband unemployed & & & & $0.114^{* * *}$ & $0.061 * * *$ & $0.053 * * *$ \\
& & & $(0.011)$ & $(0.010)$ & $(0.004)$ \\
Family nonlabor income & & & $-0.004 *$ & $-0.004 *$ & -0.000 & $(0.000)$ \\
& & & & $(0.002)$ & $(0.002)$ & 290,355 \\
N_obs & 282,656 & 282,656 & 282,656 & 290,355 & 290,355 &
\end{tabular}

Notes: Labor market outcomes of married women aged 25-64 years. Tariff changes refer to 1987-1994 and are based on effective rates of protection. Family nonlabor income is measured in thousands constant Real. TSLS estimates with TP-exNT as instrument for TP-inNT, all estimations control for state-fixed effects and year effects. Standard errors clustered at the state-level are reported in parentheses. Estimations are weighted by sampling weights. $* * * \mathrm{p}<0.01, * * \mathrm{p}<0.05, * \mathrm{p}<0.1$

\section{Conclusion}

While there is a large literature analyzing the distributional impacts of trade reforms across the income or skill distribution, very little is known about the gender effects of trade reforms. This paper seeks to fill this gap by examining the impact of the 1987-1994 trade liberalization in Brazil on female labor force participation, employment and unemployment. Brazil was one of the most heavily protected economies in the world until the late 1980s, but between 1987 and 1994 average nominal tariffs were unilaterally lowered from 54.9 to 10.2 percent and most non-tariff trade barriers were lifted.

While on aggregate the female labor force participation rate in Brazil increased from 46 to 53 percent, we show that states with greater exposure to trade liberalization experienced faster 
increases in female labor force participation and employment. These results are robust to a variety of different approaches in dealing with the potential endogeneity of regional exposure to trade liberalization, alternative measures of trade protection and different time periods, which we regard as an important validation of our identification strategy. Moreover, we find evidence that employment flows across sectors (esp. an accelerated shift from agriculture and manufacturing to trade and other services) as well as greater labor market insecurity and male unemployment are related to the observed increase in female economic activity. This suggests that both push and pull factors caused women to join the labor force.

This paper contributes in several ways to the academic literature and policy debate on the distributional and gender effects of trade liberalization. First, our analysis demonstrates that tariff reductions can affect men and women differently - because they often engage in different sectors of the economy and because married women are still more likely than men to be a secondary earner in the family. 'Gender-blind' analysis can therefore easily miss an important dimension of the labor market effects of trade liberalization.

Second, this study shows that trade reforms have important labor market spill-over effects on other sectors of the economy, including non-tradable goods and services. Analyses focusing only on the manufacturing sector (as in Wood 1991, Cagatay and Berik 1990; Ozler 2000; Pradhan 2005; Ederington, Minier and Troske 2010) thus only provide a very partial picture of the effects of tariff reforms, missing out on important general-equilibrium effects.

Finally, we caution against viewing rising female economic activity after trade liberalization unanimously as an indicator of progress. While a declining gender gap in labor force participation is arguably an important step towards greater equality between men and women in the economic sphere, one also needs to consider the reasons why women are joining the labor force. Our empirical analysis suggests that trade reforms did create new opportunities for women, but increased labor market insecurity and male unemployment most likely also induced women to join the labor force.

Related to this, we should emphasize again that our analysis focuses on the short- to medium-term effects of trade liberalization. In the longer term, migration could dampen the regional differences in the impact of liberalization. But also the push effects due to unemployment among men may be temporary, although Fernandes and Felício (2005) found that even short unemployment spells in Brazil in this period signaled substantial future earnings losses. Gaining a better understanding of the long-term dynamics as well as the transmission channels that can explain the reduced-form relationship estimated in this paper will be an important question for future research as this will have an important bearing on further policy recommendations and the question to what extent the Brazilian results can be generalized to other settings. 


\section{References}

Abreu, Marcelo de Paiva (2004) "Trade Liberalization and the Political Economy of Protection in Brazil since 1987", Working Paper SITI 08b, Institute for the Integration of Latin America and the Caribbean and Inter-American Development Bank, Buenos Aires and Washington D.C.

Acemoglu, Daron (2003), "Patterns of Skill Premia", The Review of Economic Studies 70(2): 199230.

Aguayo-Tellez, Ernesto, Jim Airola and Chinhui Juhn (2010), "Did Trade Liberalization Help Women? The Case of Mexcio in the 1990s", NBER Working Paper 16195, National Bureau of Economic Research, Cambridge MA.

Anker, Richard, Helinä Melkas and Ailsa Korten (2003), "Gender-based Occupational Segregation in the 1990s", Working Paper 16, International Labour Office (ILO), Geneva.

Balassa, Bela (1964), "The Purchasing-Power Parity Doctrine: A Reappraisal", Journal of Political Economy 72(6): 584-596.

Baslevent, Cem and Özlem Onaran (2004), "The Effect of Export-Oriented Growth on Female Labor Market Outcomes in Turkey", World Development 32(8), 1375-1393.

Becker, Gary S. (1957), The Economics of Discrimination, Second edition, University of Chicago Press: Chicago.

Becker, Gary S. (1981), A Treatise on the Family, Harvard University Press: Cambridge MA.

Becker, Gary S. (1985), "Human Capital, Effort and the Sexual Division of Labor", Journal of Labor Economics 3: 33-58.

Berik, Günseli (2000), "Mature Export-Led Growth and Gender Wage Inequality in Taiwan", Feminist Economics 6(3): 1-26.

Bhalotra, Sonia R. and Marcela Umaña-Aponte (2010), “The Dynamics of Women's Labour Supply in Developing Countries", IZA Discussion Paper 4879, Institute for the Study of Labor (IZA).

Black, Sandra E. and Elizabeth Brainerd (2004), "Importing Equality? The Impact of Globalization on Gender Discrimination”, Industrial and Labor Relations Review 57(4), 540559.

Blau, Francine D. and Lawrence M. Kahn (2007). Changes in the Labour Supply Behavior of Married Women: 1980-2000. Journal of Labor Economics, Vol. 25, No. 3: 393-438.

Bosch, Mariano, Edwin Goñi-Pacchioni and William Maloney (2012), "Trade Liberalization, Labor Reforms and Formal-Informal Employment Dynamics”, Labour Economics, forthcoming.

Boserup, Ester (1970), Woman's Role in Economic Development, St. Martin's Press, New York.

Bussmann, Margit (2009), “The Effect of Trade Openness on Women's Welfare and Work Life", World Development, 37(6), 1027-1038.

Cagatay, Nilüfer and Sule Ozler (1995), "Feminization of the Labour Force: The Effects of LongTerm Development and Structural Adjustment", World Development 23, 1883-1894.

Cagaty, Nilüfer and Günseli Berik (1990), "Transition to Export led Growth in Turkey: Is there a Feminization of Employment?", Review of Radical Political Economics, 22, 115-134.

Cain, J. Salcedo, Rana Hasan and Devashish Mitra (2010), "Trade Liberalization and Poverty Reduction: New Evidence from Indian States", Columbia Program on Indian Economic Policies, Working Paper 2010-3, School of international and Public Affairs, Columbia University.

Carvalho, Mário C. de (1992), “Alguns Aspectos da Reforma Aduaneira Recente”, Texto Para Discussão 74, Fundação Centro de Estudos do Comércio Exterior, Rio de Janeiro. 
Castilho, Marta, Marta Menéndez and Aude Sztulman (2012), "Trade Liberalization, Inequality, and Poverty in Brazilian States", World Development 40(4): 821-835.

Chamon, Marcos (1998), "Rising Wages and Declining Employment: The Brazilian Manufacturing Sector in the 1990s", Texto Para Discussão 552, Institudo de Pesquisa Econômica Aplicada (IPEA), Rio de Janeiro.

Cooray, Arusha, Isis Gaddis and Konstantin M. Wacker (2012), "Globalization and Female Labor Force Participation in Developing Countries", University of Göttingen.

Croson, Rachel and Uri Gneezy (2009), "Gender Differences in Preferences", Journal of Economic Literature 47(2): 448-474.

Ederington, Josh, Jenny Minier and Kenneth R. Troske (2010), "Where the Girls Are: Trade and Labor Market Segregation in Colombia", IZA Discussion Paper 4131, Institute for the Study of Labor.

Edmonds, Eric V., Nina Pavcnik and Petia Topalova (2010), "Trade Adjustment and Human Captial Investments: Evidence from Indian Tariff Reform”, American Economic Journal: Applied Economics 2, 42-75.

Edwards, Alejandra C. and Sebastian Edwards (1994), "Labor Market Distortions and Structural Adjustment in Developing Countries", in: Susan Horton, Ravi Kanbur and Dipak Mazumdar (eds.), Labor Markets in an Era of Adjustment. Volume 1: Issues Papers, The World Bank: Washington DC, 105-146.

Fernandes, Reynaldo and Fabiana de Felício (2005), "The Entry of the Wife into the Labor Force in Response to the Husband's Unemployment: A Study of the Added Worker Effect in Brazilian Metropolitan Areas", Economic Development and Cultural Change 53(4): 887-911.

Ferreira, Francisco H. G., Phillippe G. Leite and Matthew Wai-Poi (2010), "Trade Liberalization, Employment Flows and Wage Inequality in Brazil", in: Machiko Nissanke and Erik Thorbecke (eds.), The Poor Under Globalization in Asia, Latin America and Africa, Oxford University Press, Oxford, 199-254.

Gaddis, Isis and Stephan Klasen (2012), "Economic Development, Structural Change and Women's Labor Force Participation: A Re-examination of the Feminization U Hypothesis", University of Goettingen.

Galor, Oded and David N. Weil (1996), "The Gender Gap, Fertility and Growth", American Economic Review 86(3): 374-387.

GATT (1993a), Trade Policy Review Brazil 1992 Volume II, General Agreement on Trade and Tariffs (GATT): Geneva.

GATT (1993b), Trade Policy Review Brazil 1992 Volume I, General Agreement on Trade and Tariffs (GATT): Geneva.

Goldberg, Pinelopi K. and Nina Pavcnik (2003), "The Response of the Informal Sector to Trade Liberalization", Journal of Development Economics 72, 463-496.

Goldberg, Pinelopi K. and Nina Pavcnik (2005), “Trade Protection and Wages: Evidence from the Colombian Trade Reforms”, Journal of International Economics 66(1), 75-105.

Goldberg, Pinelopi K. and Nina Pavcnik (2007), "Distributional Effects of Globalization in Developing Countries", NBER Working Paper 12885, National Bureau of Economic Research.

Goldfajn, Ilan and André Minella (2005), "Capital Flows and Controls in Brazil: What Have We Learned?", NBER Working Paper 11640, National Bureau of Economic Research.

Goldin, Claudia (1995), "The U-Shaped Female Labor Force Function in Economic Development and Economic History”, in: T. Paul Schultz (ed.), Investment in Women's Human Capital and Economic Development, University of Chicago Press: Chicago, 61-90. 
Gonzaga, Gustavo, Naércio Menenzes Filho and Cristina Terra (2006), "Trade Liberalization and the Evolution of Skill Earning Differentials in Brazil." Journal of International Economics 68: 345-367.

Gray, Mark M., Miki Caul Kittilson and Wayne Sandtholtz (2006), "Women and Globalization: A Study of 180 Countries, 1975-2000”, International Organization 60, 239-333.

Green, Francis, Andy Dickerson and Jorge S. Arbache (2001), “A Picture of Wage Inequality and the Allocation of Labor Through a Period of Trade Liberalization: The Case of Brazil", World Development 29(11): 1923-1939.

Grigoli, Francesco (2011), "The Impact of Trade Liberalization on Business Cycle Synchronization for Mercosur Countries", European Journal of Comparative Economics 9(1): 103-131.

Heim, Bradley T. (2007), "The Incredible Shrinking Elasticities: Married Female Labor Supply, 1978-2002", Journal of Human Resources 42(4), 881-918.

Helfand, Steven M. and Luis F. Brunstein (2001), "The Changing Structure of the Brazilian Agricultural Sector and the Limitations of the 1995/96 Agricultural Census", Brazilian Review of Agricultural Economics and Rural Sociology 39(3): 179-203.

ILO (2009), "ILO Estimates and Projections of the Economically Active Population: 1980-2020 (Fifth Edition)”, International Labour Organization, Geneva. Accessed January 2010.

Jones, Ronald W. (1974), "Trade with Non-Traded Goods: The Anatomy of Inter-Connected Markets", Economica 41(162): 121-138.

Jones, Stephen R. G: and W. Craig Riddell (1999), "The Measurement of Unemployment: An Empirical Approach”, Econometrica 67(1): 147-162.

Killingsworth, Mark R. and James J. Heckman (1987), "Female Labor Supply: A Survey", in: Orley Ashenfelter and Richard Layard (eds.), Handbook of Labor Economics, Edition 1, Vol. 1, Chapter 2, Elsevier Science: Amsterdam, 103-204.

Kis-Katos, Krisztina and Robert Sparrow (2011), "Child Labor and Trade Liberalization in Indonesia”, Journal of Human Resources 46: 722-749.

Knowles, Stephen, Paula K. Lorgelly and Dorian Owen (2002), "Are Educational Gender Gaps a Break on Economic Development? Some Cross-Country Empirical Evidence", Oxford Economic Papers 54(1): 118-149.

Komiya, Ryutaro (1967), "Non-traded Goods and the Theory of International Trade", International Economic Review 32: 67-84.

Kovak, Brian K. (2011), "Local Labor Market Effects of Trade Policy: Evidence from Brazilian Liberalization”, Carnegie Mellon University.

Kume, Honorio, Guida Piani and Carlos F. B. de Souza (2003), "A Política Brasileira de Importação no Período 1987-1998: Descrição e Avaliação", in: Carlos H. Corseuil and Honorio Kume (eds.) A Abertura Comercial Brasileira nos Anos 1990 - Impactos Sobre Emprego e Salário, Ministério do Trabalho e Emprego (MTE) and Institudo de Pesquisa Econômica Aplicada (IPEA), Rio de Janeiro, 1-37.

Maloney, William F. (2004), "Informality Revisited", World Development 32(7): 1159-1178.

Melvin, Stephens Jr. (2002), "Worker Displacement and the Added Worker Effect", Journal of Labor Economics 20(3): 504-537.

Menezes-Filho, Naércio Aquino and Marc-Andreas Muendler (2011), "Labor Reallocation in Response to Trade Reform”, NBER Working Paper 17372, National Bureau of Economic Research. 
Meyer, Lisa B. (2006), “Trade Liberalization and Women's Integration into National Labor Markets: A Cross-Country Analysis”, Social Indicators Research 75, 83-121.

Muendler, Marc-Andreas (2003), "Foreign Direct Investment by Sector of Industry, Brazil 19802000", mimeo. http://econ.ucsd.edu/muendler/brazil

Oostendorp, Remco H. (2009), "Globalization and the Gender Wage Gap", World Bank Economic Review 23(1): 141-161.

Ozler, Sule (2000), "Export Orientation and Female Share of Employment: Evidence from Turkey," World Development 28, 1239-1248.

Parker, Susan W. and Emmanuel Skoufias (2004), "The Added Worker Effect over the Business Cycle: Evidence from Urban Mexico", Applied Economics Letters 11: 625-630.

Pavcnik, Nina, Andreas Blom, Pinelopi K. Goldberg and Norbert Schady (2004), "Trade Liberalization and Industry Wage Structure: Evidence from Brazil", World Bank Economic Review 18(3), 319-344.

Pereira, Lia Valls (2006), "Brazil Trade Liberalization Programme”, in: Santiago F. de Córdoba and Sam Laird (eds.) Coping with Trade Reforms: A Developing-Country Perspective on the WTO Industrial Negotiations, Palgrave Macmillan: Houndmills and New York.

Pinheiro, Armando C. (2002), “The Brazilian Privatization Experience: What's Next?”, Working Paper CBS-30-02, University of Oxford Centre for Brazilian Studies.

Pradhan, Jaya Prakash (2005), "How Do Trade, Foreign Investment, and Technology Affect Employment Patterns in Organized Indian Manufacturing?", Indian Journal of Labor Economics, 49(2): 249-272.

Priebe, Jan (2010), "Child Costs and the Causal Effect of Fertility on Female Labor Supply: An Investigation for Indonesia 1993-2008”, CRC-PEG Discussion Paper 45, Courant Research Centre 'Poverty, Equity and Growth in Developing and Transition Countries', University of Göttingen, Göttingen.

Rees, Ray and Raymond G. Riezman (2012), "Globalization, Gender and Growth", Review of Income and Wealth 58(1): 107-117.

Sauré, Philip and Hosny Zoabi (2009), "Effects of Trade on Female Labor Force Participation", Working Paper 2009-12, Swiss National Bank, Zurich.

Siddiqui, Rizwana (2009), "Modeling Gender Effects of Pakistan's Trade Liberalizaiton", Feminist Economics 15(3): 287-321.

Spletzer, James (1997), "Re-examining the Added Worker Effect", Economic Inquiry 35(2): 417427.

Standing, Guy (1999), "Global Feminization through Flexible Labor: A Theme Revisited”, World Development 27(3): 583-602.

Terra, María Inés, Marisa Bucheli and Carmen Estrades (2007), "Trade Openness and Gender in Uruguay: A CGE Analysis”, Working Paper MPIA 2008-16, Partnership for Economic Policy (PEP) and Modelling and Policy Impact Analysis (MPIA) Program.

Thoenig, Mathias and Thierry Verdier (2003), "A Theory of Defensive Skill-Biased Innovation and Globalization", American Economic Review 93(3): 709-728.

Topalova, Petia (2007), "Trade Liberalization, Poverty and Inequality. Evidence from Indian Districts", in: Ann Harrison (ed.), Globalization and Poverty, National Bureau of Economic Research and University of Chicago Press: Chicago and London.

Topalova, Petia (2010), "Factor Immobility and Regional Impacts of Trade Liberalization: Evidence on Poverty from India", American Economic Journal: Applied Economics 2: 1-41. 
Winters, Alan (1991), International Economics, Fourth Edition, Harper Collins Academy and Routledge: London and New York.

Wood, Adrian (1991), "North-South Trade and Female Labour in Manufacturing: An Asymmetry," Journal of Development Studies, 27, 168-189.

Wood, Adrian (1995), "How Trade Hurt Unskilled Workers", The Journal of Economic Perspectives 9(3): 57-80.

World Bank (2002), "Brazil Jobs Report", Report No. 24408-BR, World Bank, Washington D.C.

World Bank (2011), World Development Report 2012: Gender Equality and Development, World Bank, Washington D.C.

Yahmed, Sarra Ben (2010), "Gender Wage Discrimination and Trade Openness", GREQAM and Université de la Méditerranée. 


\section{Appendix 1: Variable Definitions}

\section{Employment rate:}

The PNAD captures various types of employment - hence our definition of employment includes employees, domestic workers, self-employed/own account workers, employers and unpaid family workers. To ensure consistency over time, we follow the recommendations in Helfand and Brunstein (2001) and construct an employment variable based on the definition used by the IBGE until 1992, which excludes unpaid family work of less than 15 hours per week and activities related exclusively to the production for own consumption. As is typically the case in official labor statistics, unpaid family work for the purpose of producing a non-marketed services (e.g. care for own children) also does not count as employment (see Gaddis and Klasen 2012 for a discussion). All employment variables refer to the primary activity carried out over the reference week of the survey (we do not consider secondary and other activities for individuals engaging in more than one economic activity). Individuals that were temporarily away from work during the reference period (e.g. due to strike, vacation, etc) are considered employed as long as they report a principal economic activity. The employment rate is defined as the ratio of the employed population to the total population (aged 25 to 64 years)

\section{Unemployment rate}

Unemployment refers to people that are not employed but actively searching for work over the past week. In the PNAD this refers to people stated they were searching for a job over the reference week and made a specific effort to find a job (e.g. contacting employers, submitting applications, consulting an employment agency or syndicate, placing advertisements, or consulting with family members, friends and colleagues). The unemployment rate is defined as the ratio of the unemployed population to the total population (aged 25 to 64 years). This differs from the standard definition of the unemployment rate, as the latter is typically defined over the labor force.

\section{Labor force participation rate}

The labor force participation rate is defined as the share of the population (aged 25 to 64 years) economically active - that is either employed or unemployed. 


\section{Appendix 2: Figures and Tables}

\section{Figure A1: Effective rates of protection by sector, 1987-1999}
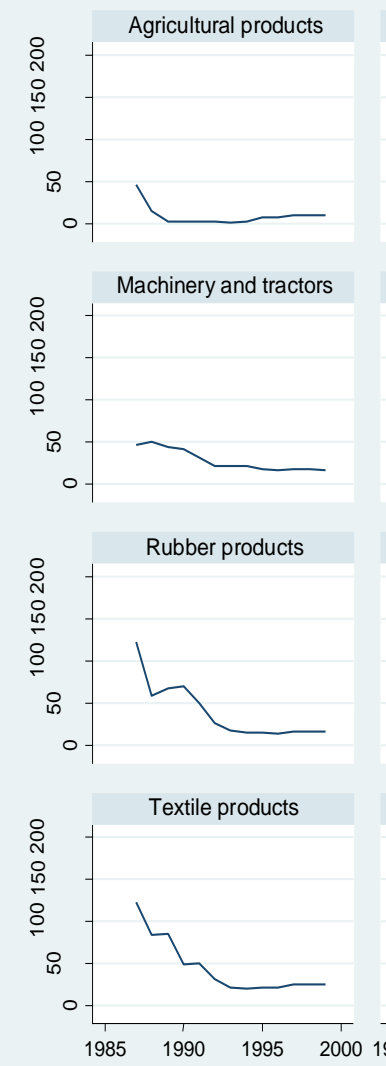

Graphs by sector

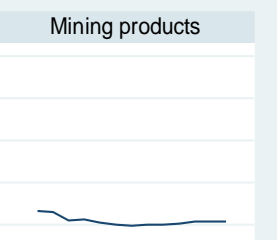

Electronic equipment

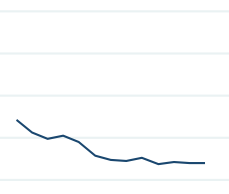

Chemical products

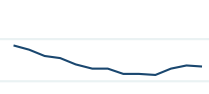

Apparel

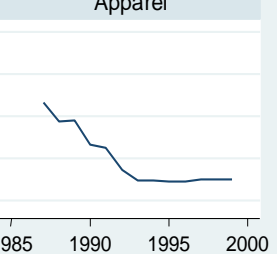

0001985

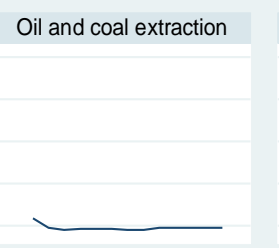

Cars and components

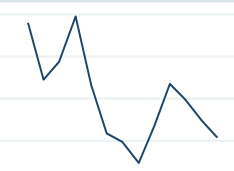

Oil refining and petrochemicals

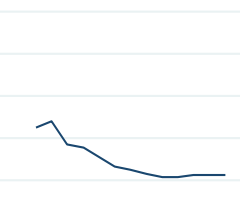

Footwear

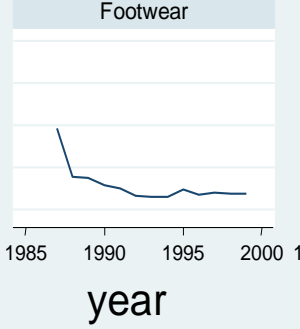

Non-metallic minerals

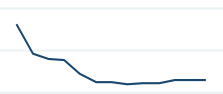

Wood products and furniture Cellulose, paper and printing
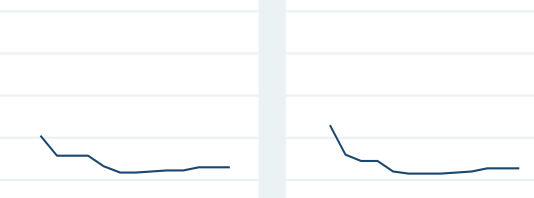

Pharmaceutical products

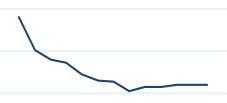

Food products

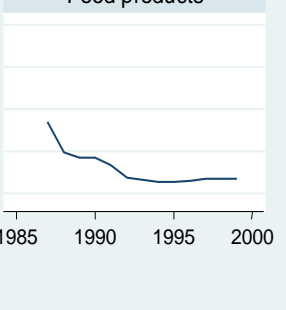

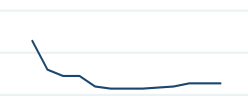

Plastic products

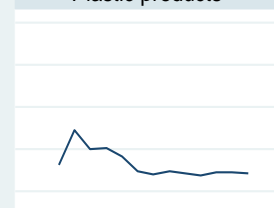

Unclassified Manufacturing
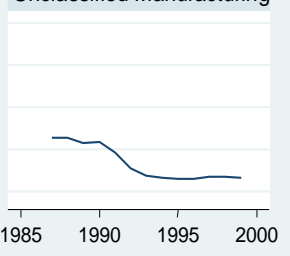

Source: Effective rates of protection from Kume, Piani and de Souza (2003), tabulated in Abreu (2004). 
Figure A2: Correlation between 1987-1994 sector tariff changes and base (1987) tariff levels

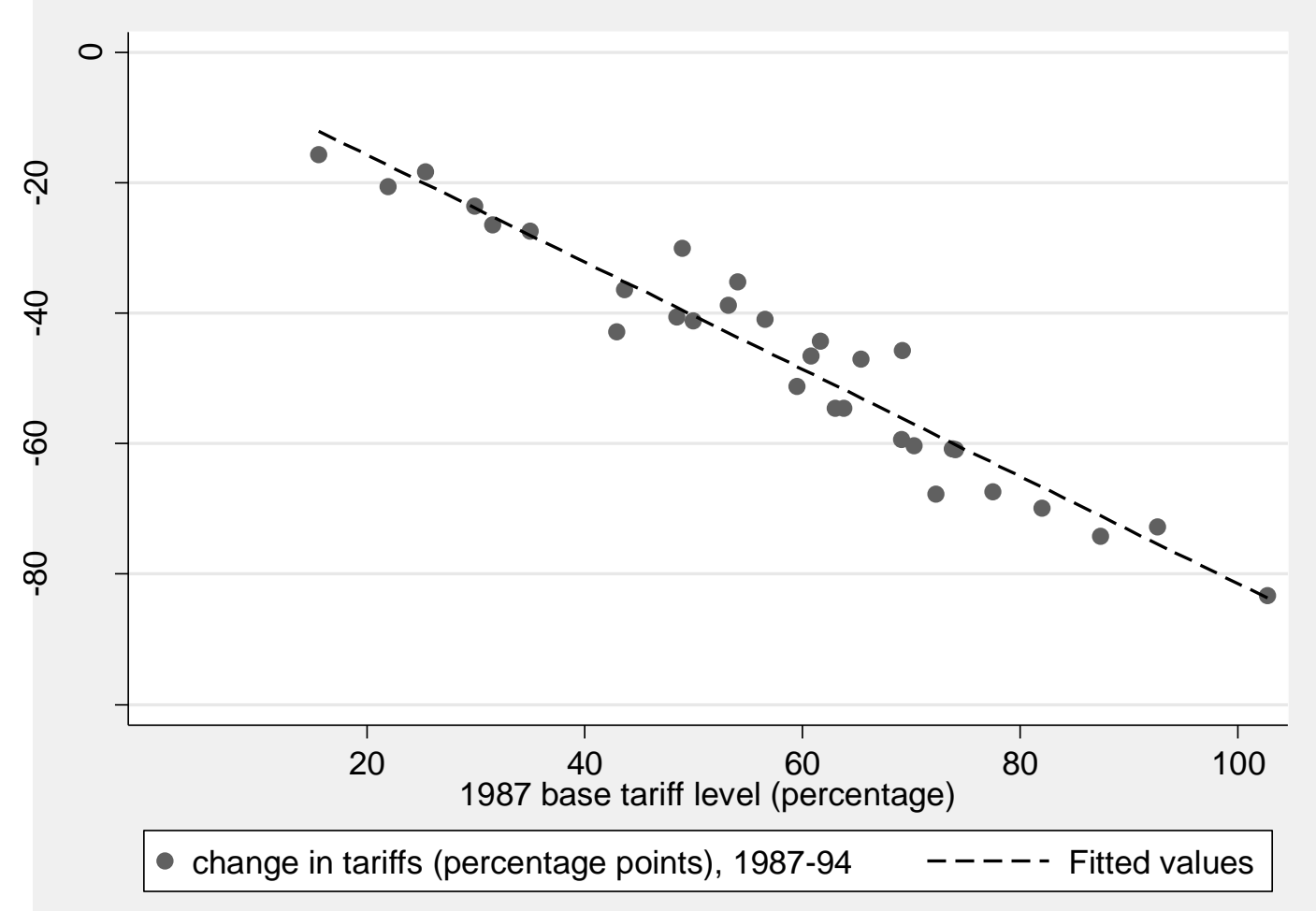

Source: Nominal tariffs from Kume, Piani and de Souza (2003), tabulated in Abreu (2004).

Figure A3: Correlation between 1994-97 sector tariff changes and base (1987) tariff levels

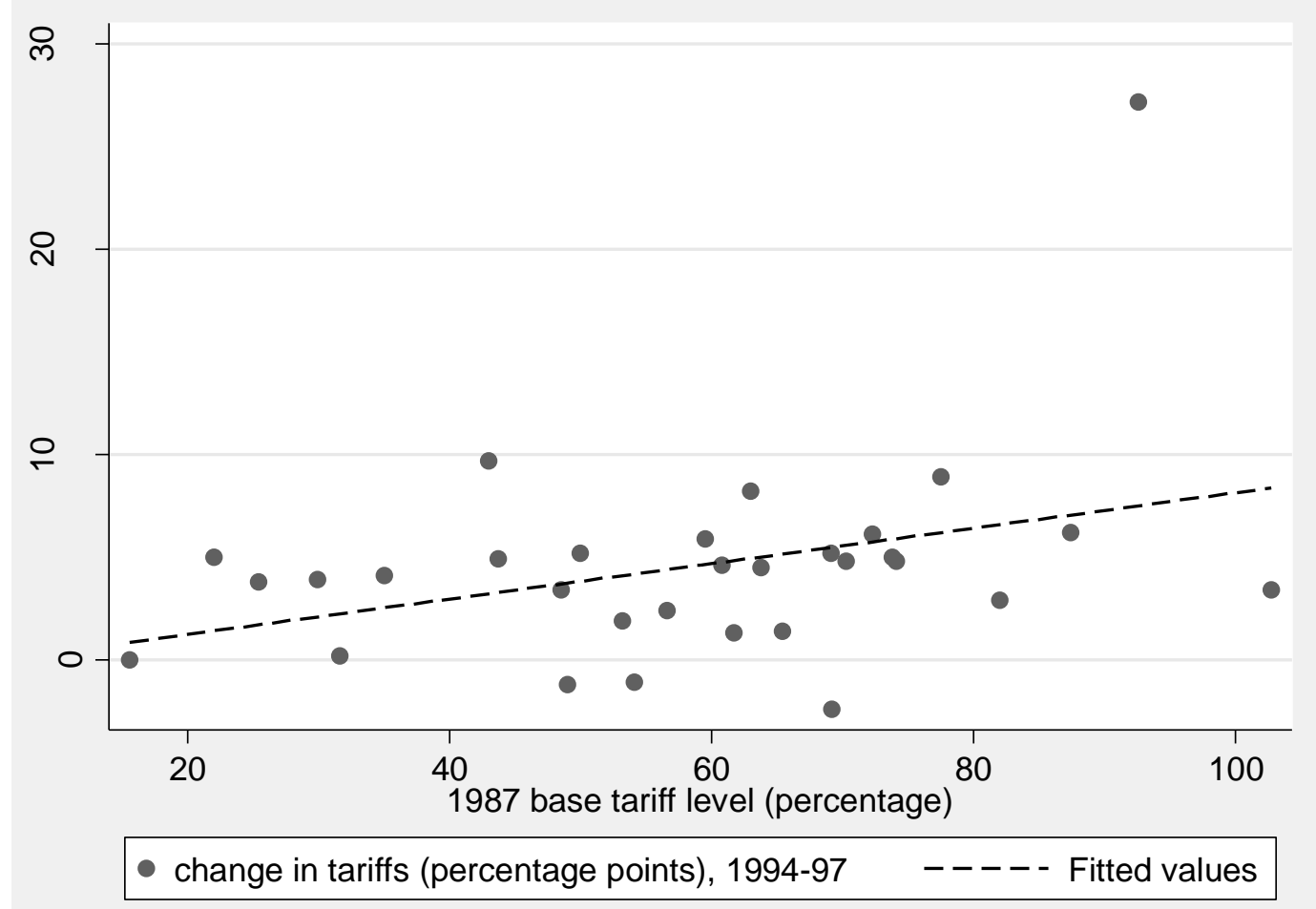

Source: Nominal tariffs from Kume, Piani and de Souza (2003), tabulated in Abreu (2004). 
Figure A4: Foreign direct investment (FDI) in Brazilian manufacturing

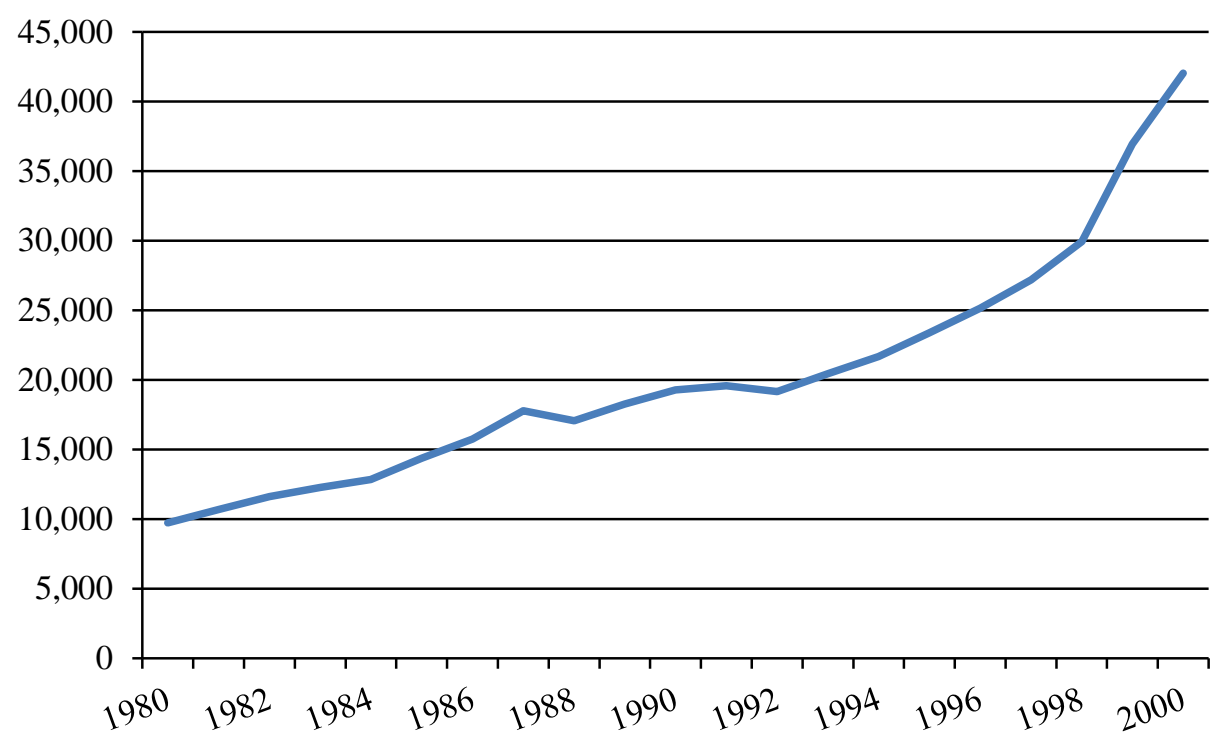

Note: vertical axis measures the stock of FDI in Brazilian manufacturing in current Mio USD. Source: Muendler (2003). 
Table A1: Sample statistics

\begin{tabular}{lrrrrrr}
\hline & \multicolumn{2}{c}{1987} & \multicolumn{3}{c}{1996} & \multicolumn{3}{c}{ All (1987-1996) } \\
\hline Labor force & 0.46 & $(0.50)$ & 0.53 & $(0.50)$ & 0.50 & $(0.50)$ \\
Employed & 0.45 & $(0.50)$ & 0.49 & $(0.50)$ & 0.47 & $(0.50)$ \\
Unemployed & 0.01 & $(0.10)$ & 0.04 & $(0.18)$ & 0.02 & $(0.14)$ \\
0-7 years schooling & 0.74 & $(0.50)$ & 0.64 & $(0.50)$ & 0.69 & $(0.50)$ \\
8-11 years schooling & 0.19 & $(0.25)$ & 0.26 & $(0.29)$ & 0.22 & $(0.27)$ \\
12 years schooling or more & 0.07 & $(0.26)$ & 0.10 & $(0.30)$ & 0.09 & $(0.28)$ \\
Number of children & 2.43 & $(1.94)$ & 2.01 & $(1.58)$ & 2.21 & $(1.76)$ \\
Age & 40.05 & $(10.96)$ & 40.64 & $(10.77)$ & 40.27 & $(10.89)$ \\
White & 0.60 & $(0.49)$ & 0.59 & $(0.49)$ & 0.59 & $(0.49)$ \\
Asian & 0.01 & $(0.09)$ & 0.01 & $(0.07)$ & 0.01 & $(0.08)$ \\
& & & & & & \\
$\mathrm{N}$ & 60957 & & 75533 & & 541687 & \\
\hline
\end{tabular}

Note: Averages for women aged 25-64, standard errors in parentheses. Source: PNAD and authors' calculations

Table A2: First stage (TSLS): TP $^{\mathrm{exNT}}$ as instrument for $T \mathrm{P}^{\mathrm{inNT}}$

\begin{tabular}{lcc}
\hline & $\begin{array}{c}\text { Grouped data estimations } \\
\text { (state panel) } \\
\text { L.TP }\end{array}$ & $\begin{array}{c}\text { Individual-level estimations } \\
\text { (pooled sample) } \\
\text { L.TP }^{\text {inNT }}\end{array}$ \\
\hline L.TP & $0.310^{\text {exNT }}$ & $0.177^{* * *}$ \\
& $(0.090)$ & $(0.062)$ \\
$\mathrm{R}^{2}$ & 0.813 & 0.826 \\
$\mathrm{~N}$ & 276 & 405197 \\
\hline \hline & & \\
& $\mathbf{L 2 . T P}^{\text {inNT }}$ & $\mathbf{L 2 . T P}^{\text {inNT }}$ \\
\hline L2.TP & $0.293^{* * * * 1}$ & $0.159^{* *}$ \\
& $(0.093)$ & $(0.063)$ \\
$\mathrm{R}^{2}$ & 0.816 & 0.830 \\
$\mathrm{~N}$ & 276 & 419176 \\
\hline
\end{tabular}

Notes: Tariff changes refer to 1987-1994 and are based on effective rates of protection. Standard errors clustered at the state-level, for 46 states, are reported in parenthesis. Grouped-data estimations are weighted by states' number of females (in 1987); individuallevel estimations are weighted by sampling weights. *** $\mathrm{p}<0.01, * * \mathrm{p}<0.05, * \mathrm{p}<0.1$ 
Table A3: Decomposition of female employment share, 1987-1995

\begin{tabular}{|c|c|c|c|c|c|c|}
\hline & \multicolumn{2}{|c|}{$\begin{array}{c}\text { Female share of } \\
\text { sector employment }\end{array}$} & \multicolumn{2}{|c|}{$\begin{array}{l}\text { Sector share in } \\
\text { total employment }\end{array}$} & \multicolumn{2}{|c|}{$\begin{array}{l}\text { Contribution to } \\
\text { change }\end{array}$} \\
\hline & 1987 & 1995 & 1987 & 1995 & within & between \\
\hline \multicolumn{7}{|l|}{ Tradables: } \\
\hline Agricultural products & 0.237 & 0.262 & 0.212 & 0.189 & 0.005 & -0.006 \\
\hline Mining products & 0.055 & 0.050 & 0.006 & 0.004 & 0.000 & 0.000 \\
\hline Oil and coal extraction & 0.042 & 0.091 & 0.001 & 0.001 & 0.000 & 0.000 \\
\hline Non-metallic minerals & 0.097 & 0.112 & 0.010 & 0.009 & 0.000 & 0.000 \\
\hline Steel, non-ferrous and other metal & 0.080 & 0.088 & 0.019 & 0.016 & 0.000 & 0.000 \\
\hline Machinery and tractors & 0.096 & 0.139 & 0.010 & 0.007 & 0.000 & 0.000 \\
\hline Electronic equipment & 0.236 & 0.228 & 0.008 & 0.005 & 0.000 & -0.001 \\
\hline Cars and components & 0.097 & 0.105 & 0.011 & 0.008 & 0.000 & 0.000 \\
\hline Wood products and furniture & 0.147 & 0.090 & 0.018 & 0.014 & -0.001 & 0.000 \\
\hline Cellulose, paper and printing & 0.207 & 0.206 & 0.009 & 0.007 & 0.000 & 0.000 \\
\hline Rubber products & 0.099 & 0.147 & 0.002 & 0.001 & 0.000 & 0.000 \\
\hline Chemical products & 0.155 & 0.176 & 0.006 & 0.005 & 0.000 & 0.000 \\
\hline Oil refining and petrochemicals & 0.163 & 0.105 & 0.002 & 0.001 & 0.000 & 0.000 \\
\hline Pharmaceutical products & 0.336 & 0.291 & 0.003 & 0.002 & 0.000 & 0.000 \\
\hline Plastic products & 0.260 & 0.306 & 0.003 & 0.003 & 0.000 & 0.000 \\
\hline Textile products & 0.493 & 0.472 & 0.012 & 0.007 & 0.000 & -0.002 \\
\hline Apparel & 0.786 & 0.790 & 0.010 & 0.009 & 0.000 & 0.000 \\
\hline Footwear & 0.471 & 0.438 & 0.006 & 0.005 & 0.000 & 0.000 \\
\hline Food products and processing & 0.223 & 0.343 & 0.026 & 0.027 & 0.003 & 0.000 \\
\hline Unclassified tradables & 0.371 & 0.435 & 0.004 & 0.004 & 0.000 & 0.000 \\
\hline Sub-total tradables & & & 0.376 & 0.323 & 0.008 & -0.012 \\
\hline \multicolumn{7}{|l|}{ Nontradables: } \\
\hline Transformation industry & 0.927 & 0.943 & 0.023 & 0.022 & 0.000 & -0.001 \\
\hline Other industry & 0.135 & 0.156 & 0.009 & 0.007 & 0.000 & 0.000 \\
\hline Construction & 0.021 & 0.018 & 0.074 & 0.070 & 0.000 & 0.000 \\
\hline Trade & 0.359 & 0.412 & 0.149 & 0.173 & 0.009 & 0.009 \\
\hline Transport & 0.048 & 0.052 & 0.041 & 0.041 & 0.000 & 0.000 \\
\hline Social services & 0.599 & 0.621 & 0.177 & 0.193 & 0.004 & 0.009 \\
\hline Other services & 0.256 & 0.259 & 0.094 & 0.099 & 0.000 & 0.001 \\
\hline Domestic services & 0.917 & 0.930 & 0.052 & 0.068 & 0.001 & 0.015 \\
\hline Unclassified non-tradables & 0.222 & 0.176 & 0.005 & 0.004 & 0.000 & 0.000 \\
\hline Sub-total non-tradables & & & 0.624 & 0.677 & 0.014 & 0.033 \\
\hline Total & 0.346 & 0.390 & 1.000 & 1.000 & 0.022 & 0.021 \\
\hline
\end{tabular}

